\title{
Perspective
}

\section{Translational Research in Late-Life Mood Disorders: Implications for Future Intervention and Prevention Research}

\author{
Gwenn S Smith*, ${ }^{*, 2}$, Faith M Gunning-Dixon ${ }^{3}$, Francis E Lotrich ${ }^{4}$, Warren D Taylor ${ }^{5}$ and Jovier D Evans ${ }^{6}$ \\ 'PET Centre, Centre for Addiction and Mental Health, Department of Psychiatry, Faculty of Medicine, University of Toronto, Toronto, ON, \\ Canada; ${ }^{2}$ Department of Psychiatry Research, the Zucker Hillside Hospital, Glen Oaks, NY, USA; ${ }^{3}$ Department of Psychiatry, Weil Medical \\ College of Cornell University, White Plains, NY, USA; ${ }^{4}$ Department of Psychiatry, Western Psychiatric Institute and Clinic, University of Pittsburgh \\ School of Medicine, Pittsburgh, PA, USA; ${ }^{5}$ Department of Psychiatry and Behavioral Sciences, Duke University School of Medicine, Durham, NC, \\ USA; ${ }^{6}$ Geriatrics Translational Neuroscience and Psychopharmacologic Intervention Programs, Geriatrics Research Branch, National Institute of \\ Mental Health, Bethesda, MD, USA
}

\begin{abstract}
Clinical and epidemiological studies have consistently observed the heterogeneous symptomatology and course of geriatric depression. Given the importance of genetic and environmental risk factors, aging processes, neurodegenerative and cerebrovascular disease processes, and medical comorbidity, the integration of basic and clinical neuroscience research approaches is critical for the understanding of the variability in illness course, as well as the development of prevention and intervention strategies that are more effective. These considerations were the impetus for a workshop, sponsored by the Geriatrics Research Branch in the Division of Adult Translational Research and Treatment Development of the National Institute of Mental Health that was held on September 7-8, 2005. The primary goal of the workshop was to bring together investigators in geriatric psychiatry research with researchers in specific topic areas outside of geriatric mental health to identify priority areas to advance translational research in geriatric depression. As described in this report, the workshop focused on a discussion of the development and application of integrative approaches combining genetics and neuroimaging methods to understand such complex issues as treatment response variability, the role of medical comorbidity in depression, and the potential overlap between depression and dementia. Future directions for integrative research were identified. Understanding the nature of geriatric depression requires the application of translational research and interdisciplinary research approaches. Geriatric depression could serve as a model for translational research integrating basic and clinical neuroscience approaches that would have implications for the study of other neuropsychiatric disorders.

Neuropsychopharmacology (2007) 32, I857-1875; doi: I0.1038/sj.npp. I 301333; published online 28 February 2007
\end{abstract}

Keywords: geriatric depression; genetics; magnetic resonance imaging; positron emission tomography (PET); neuropsychology; psychopharmacology

\section{INTRODUCTION}

In the recent commentary entitled 'Psychiatry as a Clinical Neuroscience Discipline', Insel and Quirion, 2005 discuss the importance of 'applying the revolutionary insights from neuroscience to the care of those with brain disorders.' In understanding the neurobiology of geriatric depression and developing more effective prevention and intervention strategies, the integration of basic and clinical neuroscience research is critical. Geriatric depression is characterized by substantial variability in treatment response and long-term

*Correspondence: Dr GS Smith, PET Centre, Centre for Addiction and Mental Health, Department of Psychiatry, Faculty of Medicine, University of Toronto, 250 College Street, Toronto, ON, Canada M5T IR8, Tel: + 4165358501 X7379, Fax: + 416 979-4656,

E-mail: gwenn_smith@camh.net

Received 21 August 2006; revised II December 2006; accepted 18 December 2006 illness course, as well as heterogeneity in the extent of cognitive dysfunction and structural and functional brain alterations (as reviewed by Lebowitz et al, 1997). The importance of understanding the neurobiology of geriatric depression is underscored by the association between depression in late-life and functional disability, the increased rate of completed suicide in older depressed patients, greater mortality associated with depression in the medically ill, and the increased risk for the development of Alzheimer's Disease (AD) as suggested by the epidemiological literature (Alexopoulos et al, 1996a, b; Henriksson et al, 1995; Conwell et al, 1996; Bruce and Leaf, 1989; Arfken et al, 1999; Jorm et al, 1991; Meyers and Bruce, 1998). Factors related to aging processes, medical comorbidity, cerebrovascular, and neurodegenerative disease must be considered in understanding the variability observed.

These considerations were the impetus for a workshop, sponsored by the Geriatrics Research Branch in the Division 
of Adult Translational Research and Treatment Development of the National Institute of Mental Health (NIMH) that was held on September 7-8, 2005. The primary goal of the workshop was to bring together investigators in geriatric psychiatry research with researchers in specific topic areas outside of geriatric mental health to advance translational research in geriatric depression. Investigators in the fields of genetics, neuroimaging, psychopharmacology, neuropsychology, and neuropathology presented their research. The discussion focused on integrating research findings across disciplines and identifying future directions for research. The workshop was also designed to encourage dialogue between basic and clinical researchers and to broaden crosstalk among junior, mid-career, and senior investigators. The workshop focused on developing and applying integrative approaches to understand such complex issues as treatment response variability, the role of medical comorbidity in depression, and the depression-dementia continuum. The meeting concluded with a discussion of the role of genetics and neuroimaging research approaches in the drug discovery and drug development process. It is important to note that the meeting focused on the study of unipolar major depressive disorder in the elderly, including both recurrent depression with an onset throughout the lifespan, as well as late onset depression. The meeting did not focus on the important areas of psychotic depression or bipolar disorders in the elderly that are currently the focus of large-scale, multi-center trials (eg, Meyers et al, 2005; Young et al, 2004), nor late-life anxiety disorders, which are extremely common in the elderly and represent challenges in clinical management (Flint, 1994, 1998). The following sections will focus on a summary of the status of research in genetics, structural, functional, and neurochemical imaging relevant to geriatric depression. The decision to focus on genetics and neuroimaging for the purposes of this report is that these methods best represent the interface between clinical and basic neuroscience research. Future directions for research were discussed and will be outlined at the end of the report.

\section{THE NEUROBIOLOGY OF GERIATRIC DEPRESSION}

Neuropsychological, neuroimaging, and neuropathological studies in geriatric depression have revealed deficits consistent with the normal aging process, cerebrovascular, and neurodegenerative disease processes. The integration of these data have led to the development of multifactorial models of pathophysiology (eg, Kumar et al, 2000; Alexopoulos, 2005). This section will summarize the status of research on the clinical course of geriatric depression, profiles of cognitive impairment, and neuropathological studies to provide a basis for the following discussion of neuroimaging and genetics research.

Studies characterizing the clinical course and outcomes of antidepressant treatment in geriatric depression have observed greater variability in response, increased rate of relapse, and a significant impact of age at onset, stress, and anxiety symptoms on treatment response (Reynolds et al, 1996, 1998, 1999; Dew et al, 1997; Mazure et al, 2002; Lenze et al, 2000; Flint and Rifat, 1999). Significant variability in the trajectories of acute and long-term treatment response have been observed, in addition to the observation of significant numbers of patients who are treatment resistant (about 25\% across studies; Dew et al, 1997; Little et al, 1998). It is noteworthy that geriatric patients respond as well if not better than younger patients do to electroconvulsive therapy (ECT; Tew et al, 1999; O'Connor et al, 2001). The neurobiological substrates of the differences in treatment trajectories are not well understood and are beginning to be investigated by serial cognitive and neuroimaging studies performed during the course of treatment (Nebes et al, 2003; Smith et al, 2002a, c). Clinical and epidemiological studies have identified some of the psychosocial and medical factors associated with depression, vulnerability, and prevention strategies have been evaluated in some instances (eg, bereavement, post-stroke depression, and interferon induced depression; Shear et al, 2005; Narushima et al, 2002; Whyte et al, 2004, Musselman et al, 2001). Although the choice of therapeutic agents for these prevention studies have focused on standard pharmacological and psychosocial interventions, emerging neurobiological data will potentially inform the development of novel therapeutic strategies. These strategies will be more focused on specific aspects of symptoms and cognitive deficits that are less responsive to standard pharmacotherapy.

Several domains of cognitive impairment have been reported in geriatric depression. As will be reviewed in subsequent sections, the cognitive deficits observed in geriatric depression using standard neuropsychological tests have informed the design of neuroimaging studies to visualize changes in functional neural circuitry associated with these deficits. These neuroimaging studies have used validated cognitive neuroscience approaches that are based on specific cognitive constructs. The most consistent cognitive deficits observed in depressed patients who do not meet criteria for early $\mathrm{AD}$ or other dementias, are slowed speed of processing, deficits in executive function, and memory (Kramer-Ginsberg et al, 1999; Lockwood et al, 2000, 2002; Nebes et al, 2003; Butters et al, 2000, 2004; O'Brien et al, 2004). A major focus of neuropsychological study in geriatric depression has been executive dysfunction, given the reproducibility of findings and the observation that executive function deficits often persist, despite remission of mood symptoms (Alexopoulos et al, 2002; Elderkin-Thompson et al, 2003; Lockwood et al, 2002; Nebes et al, 2001; Butters et al, 2000; Nebes et al, 2003). Executive dysfunction and/or slowed processing speed, both putative indices of fronto-striatal dysfunction, mediate other cognitive weaknesses in geriatric depression including poor visual spatial skills, and episodic memory (Butters et al, 2004; Elderkin-Thompson et al, 2004). It has been suggested that measures of executive function, compared to other cognitive domains, may have good prognostic value regarding response to treatment, whereas measures of global cognitive function and memory may identify patients 'at risk' for dementia (Lockwood et al, 2000).

Neuropathological studies are extremely important to understanding the pathophysiology of geriatric depression, interpreting the findings from clinical and neuroimaging studies and identifying new areas of in vivo mechanistic studies and therapeutic targets. The initial, preliminary neuropathological studies of patients with geriatric depres- 
sion that have been clinically well characterized before death have been published (Sweet et al, 2004; Rajkowska et al, 2005). In a sample of patients, many of whom (70\%) demonstrated cognitive deficits before death, evidence of cerebrovascular alterations, neurofibrillary tangles, amyloid plaques, and diffuse lewy bodies was observed (Sweet et al, 2004). To follow-up on reports of decreased orbitofrontal cortex volume identified on magnetic resonance scans (Lee et al, 2003), Rajkowska et al (2005) demonstrated a decreased packing density of pyramidal neurons and reductions to a greater extent in cortical layers IIIc and V, the source of prefrontal-striatal, prefrontal-cortical, and prefrontal-amygdala projections. These neuropathological studies have provided support for the observations of cerebrovascular and neurodegenerative pathology as observed with neuroimaging methods. The neuropathology of major depression with respect to neurochemical abnormalities has been reviewed extensively (Arango et al, 2002; Schatzberg et al, 2002). The majority of these studies have been performed in younger patients and the extension of these observations into older patients represents an important area of investigation. Future studies of the neuropathology of late-life depression will extend the observations made by these initial studies (Sweet et al, 2004; Rajkowska et al, 2005) to larger sample sizes and further integrate the post-mortem findings with clinical and neuroimaging methods.

\section{TRANSLATIONAL RESEARCH}

The application of an interdisciplinary research approach is critical to understanding of such issues in geriatric depression as treatment response variability, the increased morbidity, and mortality associated with depression in latelife and the role of depression as a possible risk factor for dementia. Future mechanistic research in geriatric depression is influenced by methodological developments in genetics, affective, and cognitive neuroscience and neuroimaging, by the ability to integrate information across different research modalities and by using the information obtained to generate new hypotheses and therapeutic strategies. The following sections will summarize the existing literature in structural, functional, and neurochemical brain imaging and genetics, as well as the integration of these approaches. Future directions for translational research studies will be described. It is important to note that in some areas, the data reviewed will focus on studies in geriatric depression. In other areas, in which limited data in older subjects is available, the discussion will include the identification of methodological issues relevant to the study of geriatric patients and the identification of directions for research based on data obtained in younger depressed patients.

\section{Neuroimaging Research}

Converging evidence from clinical, neuroimaging, and neuropathological studies suggest that biological susceptibility to geriatric mood disorders is likely mediated by compromise in fronto-striatal-limbic functions with contributions from genetic, vascular, neurochemical, neuro- degenerative, and other aging-related factors. Structural and neurochemical imaging methods, in addition to neuroimaging studies using cognitive and affective neuroscience approaches can be used to investigate the relationship among potential contributing factors to neural network abnormalities, and relate these findings to the clinical features and course of geriatric mood disorders. The following sections will provide a review of the literature concerning the application of structural, functional, and neurochemical imaging methods, comments regarding the findings in these three areas and the identification of future research directions for geriatric depression.

\section{Structural brain imaging.}

Introduction: Structural magnetic resonance (MR) imaging studies of geriatric depression have emphasized two lines of research: the evaluation of gray matter volumes and cortical and subcortical gray and white matter hyperintensities (Krishnan, 2002; Alexopoulos, 2005). Structural alterations have been observed in many components of the cortico-striatal limbic networks implicated in depression that have been described in the literature (eg, Mayberg, 2003; Adler et al, 2006).

The consistency of such findings as white matter hyperintensities and hyperintense areas in subcortical gray matter structures has drawn attention to the role of cerebrovascular disease in geriatric depression (Greenwald et al, 1996, 1998; Krishnan et al, 1997; Taylor et al, 2005a). These observations have led to the 'vascular depression hypothesis' (Krishnan et al, 1997; Alexopoulos et al, $1997 \mathrm{a}, \mathrm{b})$. This hypothesis is supported by the observations that there is a high rate of depression in patients with hypertension, diabetes, and coronary artery disease. There is also a high rate of depression in patients who have had strokes and/or silent strokes. White matter hyperintensities frequently occur in late onset depression. Vascular features in geriatric depressed patients are associated with greater overall cognitive impairment, greater impairments in word fluency, and naming, more psychomotor retardation, less agitation, less guilt feelings and greater lack of insight. These symptoms were observed to be similar to a frontal lobe syndrome that would result from disruption of cortico-striato-pallido-thalamo-cortico pathways (Alexopoulos et al, 1997a).

Summary of the literature: The primary volumetric findings in geriatric depression compared to comparison subjects include decreased gray matter volumes in prefrontal, anterior cingulate, and orbitofrontal cortex hippocampus, amygdala, and basal ganglia (O'Brien et al, 2004; Ballmaier et al, 2004; Bremner et al, 2002; Lai et al, 2000; Lee et al, 2003; Ballmaier et al, 2004; Krishnan, 1993; Kumar et al, 1998; Sheline et al, 1996, 1998, 1999; Ashtari et al, 1999). With respect to clinical correlates of these findings, the primary observations are the association between reduced hippocampal volume and later age-of-depression onset (Steffens et al, 2000, 2002), vascular risk factors, such as coronary artery disease (Koschack and Irle, 2005), and repeated episodes of depression (Bell-McGinty et al, 2002; Butters et al, 2000; Sheline et al, 1996, 1999, 2003) and greater degree of atrophic changes associated with poorer 
treatment outcome (Pillay et al, 1998; Young et al, 1999). It has been suggested that antidepressant treatment may reverse some of these volume reductions (Jacobs et al, 2000; Vythilingam et al, 2004).

Gray and white matter hyperintensities, particularly in the deep gray matter, in geriatric depressed patients have been associated with poorer performance compared to depressed patients without such lesions or normal elderly subjects with or without deep white matter changes in multiple domains of cognition including general and delayed recall memory measures (Wechsler Memory Scale-general memory index, delayed recall index), executive functioning (animal naming test), and language testing (Boston Naming Test) (Lesser et al, 1996; Kramer-Ginsberg et al, 1999). Several studies have also demonstrated that poorer treatment outcome is associated with greater subcortical and white matter hyperintensities (Fujikawa et al, 1996; Hickie et al, 1995; Leuchter et al, 1997; Simpson et al, 1997; Steffens et al, 2001).

Comment: Several recent methodological developments with respect to MR sequence development and analytic methods will have an important impact on the evaluating of volumetric alterations, the detection of white matter changes and the ability to visualize connectivity. Higherresolution images acquired at higher magnetic field strengths, new methods of shape analysis (Posener et al, 2003; Styner et al, 2004) and the use of data-driven, voxel based approaches, may yield novel observations of structural brain alterations and the relationship to course of illness.

More sophisticated methods have been developed to evaluating white matter lesions quantitatively (Firbank et al, 2004) and with improved regional localization (Macfall et al, 2005). Diffusion tensor imaging has been used to examine the biophysical characteristics of white matter and for fiber tract mapping (Pierpaoli and Basser, 1996; Wakana et al, 2004). In patients with geriatric depression there is preliminary evidence to demonstrate frontal and temporal cortical differences in white matter structure in older depressed subjects (Nobuhara et al, 2006; Taylor et al, 2004), as well as alterations in specific anterior regions that were associated with poorer antidepressant response (Alexopoulos et al, 2002). Magnetization transfer is a method that may be particularly sensitive to detecting changes in myelin-related proteins and hence of great use in demyelinating disorders. This technique may reveal areas that may be compromised in normal-appearing regions in older depressed subjects (Kumar et al, 2004). The development and implementation of these new MR sequences has the potential to contribute unique pathophysiological information with respect to cerebrovascular and neurodegenerative mechanisms underlying white matter pathology in geriatric depression.

Future directions: The observations of structural changes in the brains of patients with geriatric depression should be further integrated with clinical and cognitive measures, genetics and functional imaging data to understand the significance of the structural changes and to address such questions as: (1) are structural brain changes related to differential treatment response or cognitive deficits; (2) what is the relationship between structural brain alterations and genetic polymorphisms that have been associated with antidepressant response, cognitive function, and neurotrophic factors; (3) how do structural changes relate to a differential functional response to cognitive or pharmacological activation? Another critical aspect of future MR research is studies to correlate the neuroimaging findings with post-mortem data. The objectives of such studies are to identify the pathophysiology underlying the alterations in gray matter volumes and in the white matter hyperintensities, addressing whether these white matter changes are owing to cerebrovascular compared to demyelinating processes, an issue that has been debated for over two decades (George et al, 1986a,b; Thomas et al, 2002).

\section{Functional imaging: cognitive, and affective neuroscience approaches.}

Introduction: As described in the introduction deficits in executive function, speed of processing, and memory have been the major findings of neuropsychological studies in geriatric depression. Thus, the integrity of fronto-striatal and fronto-limbic circuitry hypothesized to underlie these deficits has been the major focus of cognitive and affective activation studies in geriatric depression. The following section will briefly summarize these findings, in addition to other promising areas of research in younger patients that may have important applications to the study of older depressed patients.

\section{Summary of the literature:}

1. With respect to affective processing, neuroimaging studies in young and middle aged individuals with major depression have most consistently shown abnormal activation in fronto-limbic regions specifically hyperactivation of ventral limbic regions. In contrast, executive processing is usually accompanied by hypoactivation of dorsolateral prefrontal and dorsal anterior cingulate regions (eg, Canli et al, 2004; Davidson et al, 2003; Elliott et al, 2002; Surguladze et al, 2005; Rose et al, 2006).

2. Preliminary studies in patients with late-life depression using executive (standard Stroop task) and affective (emotional Stroop task) tasks suggest that relative to comparison subjects, elderly depressed patients show less activation of the dorsal anterior cingulate during executive processing and greater activation of the subgenual cingulate and dorsomedial prefrontal cortex in response to negatively valenced words (GunningDixon et al, 2005).

3. Verbal fluency tasks (eg, phonemic word generation) demonstrated bilateral hypoactivation of the dorsal anterior cingulate and the hippocampus in severely depressed geriatric patients relative to comparison subjects (de Asis et al, 2001) with the disruption in hippocampal activation in depressed patients predicting poor memory performance.

4. Explicit sequence learning tasks have shown in patients, compared to age-matched comparison subjects, decreased prefrontal activation in addition to increased caudate activation (Aizenstein et al, 2005b). 
5. With respect to episodic memory, patients with geriatric depression demonstrate decreased activation of temporo-limbic structures relative to control subjects, but a greater response of these regions and potentially a greater capacity for compensation compared to $\mathrm{AD}$ patients (Gron et al, 2002).

Comment: The systematic evaluation of the activation response in normal aging and the comparison of the activation responses in younger compared to older depressed patients represent two priorities for functional neuroimaging studies. Such studies would have implications for the understanding of the contribution of agerelated changes in brain function to the pathogenesis of geriatric depression, as well as the understanding of abnormalities or compensatory mechanisms that may be associated with the onset of depression in late life, as well as the impact of repeated depressive episodes. Results from fMRI studies of non-depressed older adults provide evidence for the vulnerability of fronto-limbic regions to the influence of aging. While processing affective stimuli, older adults reveal diminished activation of the amygdala relative to younger adults (Gunning-Dixon et al, 2003; Iidaka et al, 2002; Tessitore et al, 2005), within the context of the older adults demonstrating greater activation of prefrontal regions than the young comparison groups (Gunning-Dixon et al, 2003; Tessitore et al, 2005). Activation results from both episodic memory and executive function studies indicate that older adults often recruit additional frontal regions when compared with young adults (Cabeza et al, 2000, 2002, 2004; Lamar et al, 2004; Nielson et al, 2002, 2004). Thus, these data suggest that the activation patterns in older depressed individuals may differ from the patterns observed in young and middle-aged depressed patients and the direct comparison of these groups may provide important information about the influence of aging-related brain changes on the pathophysiology of geriatric depression.

With respect to the application of recent methodological advances, correlating the time course of the blood oxygen level-dependent response between brain regions can be used as a measure of functional connectivity and is a promising technique that has only recently been applied to the study of geriatric mood disorders. In a study of geriatric depression, Aizenstein et al (2005a) used an executive probe in an event-related fMRI paradigm to activate the dorsolateral prefrontal cortex and the dorsal anterior cingulate. During baseline scanning, depressed patients revealed hypoactivation of the dorsolateral prefrontal cortex and the anterior cingulate as well as decreased functional connectivity between these regions relative to comparison subjects. Hypoactivation in these regions resolved following 12 weeks of treatment with paroxetine, but the decreased functional connectivity persisted (Aizenstein et al, 2005a). Furthermore, preliminary evidence suggests that abnormal activation of some regions may resolve with treatment, whereas a lack of functional connectivity between regions may persist. Coupled with the findings summarized above, this study suggests that not only specific regions of frontostriatal and fronto-limbic networks exhibits abnormal activation, but a disconnection syndrome affecting these systems may exist in geriatric depression.
Future directions: Although traditional neuropsychological tests have contributed valuable data about the general cognitive domains affected in geriatric depression, these tests assess complex cognitive functions that are not ideal for studies of specific neural networks. In contrast, simpler cognitive tests, in some cases originating from non-human primate studies of neural circuitry should be used to study of specific cerebral network abnormalities in geriatric depression. Examples of such assessments are the tests included in the Cambridge Neuropsychological Test Automated Battery (Sahakian and Owen, 1992). This battery includes tests developed to evaluate the neural substrates of cognition in non-human primates that were adapted to the study of human subjects. Some of the tests have been evaluated using fMRI and psychopharmacologic interventions to characterize further the neural circuitry and neurochemical mechanisms underlying task performance. One example of the application of a well-characterized cognitive paradigm to geriatric depression is the study by Murphy and Alexopoulos (2006) who have used the well-established Attention Network Test (Fan et al, 2002) to assess the efficiency of the executive, orienting, and vigilance attention networks and their association to treatment response in older patients with major depression. Preliminary evidence indicates that executive-related performance, but not orienting- or vigilance-related performance, was correlated with time to remission.

In addition to characterizing changes in cerebral activation patterns following treatment, functional MRI should be used to identify cerebral network abnormalities that predict treatment outcomes, including core depressive symptoms, as well as cognitive deficits. An example of such a study in younger depressed patients, greater activation in the amygdala in response to emotional facial expressions predicted better treatment outcome several months following treatment, even after controlling for depression severity and medication status (Canli et al, 2005). The use of cognitive and affective fMRI paradigms within the context of controlled treatment trials for geriatric depression would not only advance our knowledge of the pathogenesis of geriatric depression, but also allow us to identify biomarkers of individuals who are at risk for poor treatment responses.

Further studies comparing cognitive and affective activation responses in patients with geriatric depression and $\mathrm{AD}$ (especially longitudinal studies in subjects who decline cognitively compared to those who do not) may be useful in identifying whether there are overlapping or independent patterns of neurodegeneration in geriatric depression compared to $\mathrm{AD}$. The evaluation of medication effects would address the issue of whether antidepressant agents improve function and whether treatment with cognitive enhancing agents may be indicated.

Our understanding of the nature and role of frontostriatal-limbic network anomalies in the presentation and course of geriatric depression may be enhanced significantly by the combination of fMRI with other imaging modalities. For example, rapid advancements in imaging processing and analysis techniques should enable combination of data across fMRI and DTI-imaging modalities allowing a more comprehensive analysis of functional connectivity in geriatric depression. 
Neurochemical imaging approaches.

Introduction: The major emphasis of neurochemical imaging studies using positron emission tomography and single photon emission computed tomography in major depressive disorder has been the evaluation of the monoamine hypothesis of affective disorders (Schildkraut, 1965). Advances in radiochemistry over the past two decades have made possible the visualization of monoamine metabolism, transporter and receptor binding, as well as other potentially relevant neurochemical mechanisms (as reviewed by Fowler et al, 2003; Smith et al, 2004)). There are other approaches for evaluating neurochemical function including the combination of pharmacologic challenges with the measurement of cerebral blood flow and glucose metabolism in the resting state or during cognitive or affective processing tasks. MR spectroscopy studies can potentially complement the PET and SPECT imaging methods and permits the evaluation of concentrations of amino acids (GABA, glutamate) and membrane lipids in the brain. For example, studies conducted in patients with geriatric depression have demonstrated increased myo-inositol/ creatine ratios in frontal white matter (Kumar et al, 2002).

Summary of the literature: The PET and SPECT studies performed thus far have been conducted mainly in patients with midlife depression. The major findings of the studies comparing depressed patients to demographically matched comparison subjects are (1) reduced serotonin precursor uptake and synthesis (Agren et al, 1991; Rosa-Neto et al, 2004); (2) modest or no reductions in serotonin transporter, 5-HT1A, and 5-HT2A binding (Malison et al, 1998; Meyer et al, 2004, 2001a, c; Parsey et al, 2006; Drevets et al, 1999; Sargent et al, 2000; Meltzer et al, 1999; Zanardi et al, 2001; Yatham et al, 1999); (3) modest changes in dopamine metabolism, dopamine transporter, and D1 and D2 receptor binding (Agren and Reibring, 1994; Meyer et al, 2001b; Suhara et al, 1992) and (4) most recently, a significant (average 34\%) elevation of monoamine oxidase A concentrations in depressed patients compared to comparison subjects (Meyer et al, 2006). Thus, studies of monoamine transporter and receptor binding have shown limited sensitivity in differentiating depressed patients from comparison subjects. Studies evaluating the PET measures relative to symptom and genetic measures have observed (1) increased serotonin transporter and 5-HT2A binding associated with negative dysfunctional attitudes (Meyer et al, 2003, 2004); and (2) higher 5-HT1A binding associated with no previous antidepressant treatment, poorer antidepressant outcome and homozygosity for the functional 5-HT(1A) G(-1019) allele of the promoter polymorphism (Parsey et al, 2006). Thus, the variability in transporter and receptor binding may be explained by symptom or genetic factors.

Comments: As described above, relatively modest changes in transporter and receptor binding in patients compared to comparison subjects have been observed. In addition, a lack of correlation between the magnitude of occupancy of a drug to the initial target site of action with clinical response has been observed across a variety of disorders, including SSRIs in patients with depression, antipsychotics in patients with schizophrenia, cholinester- ase inhibitors in Alzheimer's disease (eg, Meyer et al, 2004; Wolkin et al, 1989; Farde et al, 1992; Kuhl et al, 2000). These observations suggest that measuring the dynamic aspects of monoamine function may be more revealing of pathophysiology and treatment mechanisms than measures of transporter or receptor binding.

On the basis of these observations, methodology development was initiated over a decade ago to evaluate dynamic measure of monoamine function and interactions between monoamine systems The early focus of this work was on the measurement of striatal dopamine concentrations (eg, Dewey et al, 1993; Volkow et al, 1994) and modulation by other neurotransmitter systems (eg, serotonin, glutamate; as reviewed by Smith et al, 2004). Thus far, studies have not observed differences in striatal dopamine concentrations in midlife depressed patients (Anand et al, 2000; Parsey et al, 2001). However, developments in the imaging of extrastriatal D2/D3 receptor in cortical and limbic related areas (including the ventral striatum; Willeit et al, 2006) may have important implications for imaging dopamine function in brain regions that may be more relevant to depression and reward circuitry. The potential role of dopamine as a therapeutic target has been suggested by recent methylphenidate augmentation studies (Lavretsky and Kumar, 2001).

More recent studies have focused on the development and application of a method to measure serotonin function in vivo (Meyer et al, 1999; Hume et al, 2001; Smith et al, 1999, 2002b, 2004). Studies conducted thus far in geriatric depression combining acute and chronic SSRI treatment (citalopram) with measures of cerebral glucose metabolism have shown a differential lateralized pattern of acute metabolic effects in the patients in contrast to comparison subjects that are similar to the response in normal subjects who have a s allele of the serotonin transporter promoter polymorphism compared to those normal subjects with a 1 allele (Smith et al, 2004).

Thus, in the case of depressive disorders the combination of $\mathrm{rCBF}$ or glucose metabolism measures with a pharmacologically selective intervention may further enhance the predictive value of these measures with respect to identifying the functional differences between treatment responders and non-responders. After identifying the functional neuroanatomic changes, mechanistic studies using neuroreceptor radiotracers can be designed based on the functional circuitry altered to identify the neurochemical substrates underlying the metabolic effects. Similar pharmacologic intervention studies could be conducted with fMRI methods and would be extremely informative, especially with respect to monoamine regulation of the neural circuitry involved in cognition.

Future directions: The application of neurochemical imaging methods has focused on the investigation of monoamine transporters and receptors in depression and occupancy by antidepressant medications. Much of this work has been performed in younger patients. Some of the most intriguing results obtained thus far have involved integrating the neurochemical imaging measures with clinical variables and genetic polymorphisms.

The question embedded in this discussion is why these transporter and receptor measures are not more sensitive to 
identifying pathophysiology, especially in brain regions that have shown glucose metabolic alterations. The limited data available in geriatric patients suggest that these effects are even more modest in older compared with younger patients (eg, Meltzer et al, 1999). Is the lack of a more dramatic effect telling us something about the adaptive function and compensatory mechanisms of these systems? As described, dynamic measures of monoamine function may be more sensitive than static measures such as transporter or receptor availability. Regarding other potentially relevant neurochemical systems, radiotracers development for both adrenergic and glucocorticoid systems are active areas at the present time, and development of radiotracers for these systems would have important implications for mechanistic studies in geriatric depression. Another important area of investigation would be to understand further the mechanism of action of antidepressant medications relative to promoting trophic responses in geriatric depressed patients as has been shown in laboratory animals (Duman et al, 1997).

PET methods can be applied to examine specific neurodegenerative processes in vivo that have been characterized in the post-mortem brain in patients with depression and with AD. In vivo imaging can be applied to evaluate when the neuropathologic process emerges in the illness and how it relates to the course of the illness with respect to treatment response and onset of cognitive impairment. As amyloid deposition has been observed in the brains of geriatric depressed patients, amyloid imaging agents would be important to evaluate in patients relative to cognition dysfunction (Sweet et al, 2004; Klunk et al, 2004). In addition, given the reports of increased neuroinflammatory markers in post-mortem brain and increased concentrations of pro-inflammatory cytokines in plasma (Thomas et al, 2000, 2005), the use of the peripheral benzodiazepine radiotracer [ ${ }^{11} \mathrm{C}$ ]-PK 11195 (Groom et al, 1995) would be extremely interesting to evaluate in patients with and without cerebrovascular disease and also to evaluate the impact of antidepressant medication and other pharmacologic interventions. Another aspect of understanding neurodegeneration and cognitive impairment in geriatric depression is the application of radiotracer-binding methods to elucidate a potential cholinergic deficit. Preliminary post-mortem studies in geriatric depression report pathological changes in both monoaminergic and cholinergic neurons in geriatric depression (Sweet et al, 2004). The cholinergic system in depression is very much understudied. On the basis post-mortem studies in mild cognitive impairment and $\mathrm{AD}$, there may be evidence of a compensatory cholinergic process early in the course of cognitive impairment and an actual cholinergic deficit may not appear until the later stages of impairment (DeKosky et al, 2002). The cholinergic system may similarly be involved as substrate of cognitive deficits in geriatric depression

Other aspects of geriatric depression research that merit further neurochemical imaging studies include the comparison of younger depressed patients to older depressed patients to determine whether the initial onset of depression in mid-life compared to late-life patients involves the same neurochemical substrates and to determine the impact of repeated depressive episodes on neurochemical function. Such studies are critical in addressing such fundamental questions as to whether depression in late-life is a distinct neurochemical entity, whether there are distinct neurochemical alterations that occur in patients who develop dementia, whether depression is a neurobiological prodrome of dementia or a consequence of neuronal loss. The mechanism of action of interventions that are effective in treatment-resistant patients such as ECT should be further investigated. The neurobiological effects of such treatments remain poorly understood (Mann, 1998; Szuba et al, 2000). Mechanisms such as greater enhancements of monoaminergic function and increased trophic responses have been suggested to underlie the greater efficacy of ECT compared to antidepressant medications. Finally, neurochemical imaging studies in psychosocial (bereavement; Shear et al, 2005) and medical (interferon induced depression; Musselman et al, 2001) circumstances, in which depressive symptoms occur in a subset of vulnerable individuals would be extremely interesting in terms of identifying neurobiological markers of vulnerability. Similar considerations apply to geriatric bipolar disorder and psychotic depression. These disease entities are studied conditions that are clinically challenging and associated with cognitive deficits and increased mortality in the case of psychotic depression (Vythilingam et al, 2003).

\section{Genetics research.}

Introduction: Genetic influences may be associated with vulnerability to both psychosocial and medical triggers of depression, as well as variable phenotypic expression and treatment sensitivity. As the data regarding candidate gene studies and pharmacogenetic studies have been reviewed extensively (eg, Nemeroff and Vale, 2005; Hattori et al, 2005; Paez-Pereda, 2005; Craddock and Forty, 2006; Binder and Holsboer, 2006; Lesch and Gutknecht, 2005; Serretti et al, 2005; Wong and Licinio, 2004; Levinson, 2006), this section will primarily focus on observations relevant to future genetic association studies of geriatric depression.

Summary of the candidate gene selection literature: In one of the few studies conducted in elderly subjects, the serotonin transporter promoter has been associated with depression following a hip fracture in the elderly (Lenze et al, 2005), consistent with the interaction of this polymorphism with psychosocial stress (Caspi et al, 2003). However, most candidate genes have been primarily examined in younger populations. These include enzymes for serotonin synthesis (Zhang et al, 2005; Zill et al, 2004), serotonin transporters and receptors (5-HT1A and 5-HT2A receptors, Lesch et al, 1996; Arias et al, 2005), the norepinephrine transporter (as reviewed by Leonardo and Hen, 2006), second-messenger systems (eg, Zubenko et al, 2002), glucocorticoids (Van Rossum et al, 2006; van West et al, 2006), neuroendocrine hormones (Binder et al, 2004) and brain-derived neurotrophic factor (BDNF: eg, Rybakowski et al, 2003; Strauss et al, 2004). These genes may have either much weaker or more predominant roles in older adults, hypotheses that await testing.

Previously unsuspected candidate genes are also being identified using genomic micro-arrays, animal studies, and genome-wide searches (Bunney et al, 2003), with potential sources of messenger ribonucleic acid (mRNA) from post- 
mortem brains (Evans et al, 2004; Erraji-Benchekroun et al, 2005; Sibille et al, 2004), brain tissue from animal models of depression (Yamada et al 2001, 2000; Landgrebe et al, 2002; Alfonso et al, 2004), peripheral sources such as lymphocytes in living depressed subjects (Gladkevich et al, 2004), and cell cultures (Chen et al, 2003). Fibroblast growth factor gene expression was shown to be dysregulated in post-mortem brain tissue from depressed patients (Evans et al, 2004). Growth associated protein mRNA was increased in hippocampal cultures following desipramine treatment (Chen et al, 2003). Electroconvulsive stimulation in rodents identified potential roles for BNDF, second-messenger systems involving cAMP and related neurotrophic factors (Altar et al, 2004). In combination, studies such as these provide possible clues, regarding which gene systems, such as those involved in neurogenesis, to examine further in associational analyses. However, an important consideration is that many mRNA transcripts may change either with healthy aging or with other age-related disease processes (Lukiw, 2004; Ricciarelli et al, 2004; Toescu et al, 2004). Thus, it will be crucial to consider the aging process and associated disease processes in interpreting data specifically related to geriatric depression.

Whole genome associational studies are utilizing dense maps of genetic variation to examine the entire genome for possible candidates (Craig and Stephan, 2005; Ehm et al, 2005). A recently completed haplotype map of the human genome (Altshuler et al, 2005) has provided a dense array of SNPs for use in several different populations. The technology for this whole genome approach is nascent but should also provide a complimentary approach to hypothesis-based studies of genetic association.

Pharmacogenetic studies performed thus far in patients with geriatric depression have observed associations between speed of response and antidepressant side effects and the serotonin transporter promoter polymorphism (slower spend of response and greater side effects response associated with the s allele; Pollock et al, 2000; Murphy et al, 2004). Future pharmacogenetic studies will require controlling for differences in exposure to the pharmacologic stimulus (Lotrich et al, 2006). In particular, there can be large variability in exposure to medications, which may be an important confound to address, as different genotypes may be associated with dissimilar concentration-response relationships (Lotrich et al, 2006). This is particularly salient in the elderly who can have substantial variations in drug concentrations as well as markedly different sensitivities to medications (Lotrich and Pollock, 2005b).

Comment: Future genetic association studies should include (i) an explicit account of the selection of candidate genes and haplotypes, with appropriate statistical control for multiple testing, (ii) a comprehensive description of the psychiatric phenotype including course, pattern, and comorbidity, given the likely complexity of geriatric depression, (iii) statistical attention to the potential for population stratification, an issue that can be particularly problematic in neuroimaging studies with small sample sizes, and (iv) an analysis of linkage between polymorphisms within a gene and the potential for intra-genetic epistasis.
In geriatric depression, many co-morbidities are frequently present, most notably vascular disease and inflammation. For example, consistent with proposed theories that inflammatory cytokines induce a subtype of geriatric depression, late-life depression is associated with increases in interleukin $1 \mathrm{~b}$ (Thomas et al, 2005), elevated interleukin 6 (Tiemeier et al, 2003), and an enhanced inflammatory response (Glaser et al, 2003). These co-morbidities may influence the relative role of genes in late life. Several possible causal genetic pathways have been suggested: (i) genes influence co-morbid illness that subsequently causes depression, (ii) genes moderate the ability of co-morbid illness to cause depression, (iii) genes directly influence depression that subsequently triggers co-morbid illness, (iv) genes moderate the ability of depression to cause a comorbid illness, and (v) similar genes simultaneously influence both depression and co-morbid illness. Prospective studies will be needed to dissect the role of genetic vulnerability in these bi-directional pathways. The observation that comorbidity with depression is the rule rather than the exception suggests that these complex diagnostic issues should not be ignored in neurobiological studies of late-life mood disorder. Several of these hypotheses may be addressed in future studies that integrate neuroimaging studies with genetics, a technique reviewed in later sections.

For interpreting forthcoming associational studies, genetic influences on protein expression and function will require characterization. For instance, a common single nucleotide polymorphisms (SNP) in the upstream regulatory region for tryptophan hydroxylase 2 (TPH2) has recently been associated with changes in amygdala reactivity (Brown et al, 2005) during midlife, and may affect binding for several transcriptional regulators such as MSX-1 and MSX-2. However, whether this polymorphism is functional, whether this functionality changes with age, or whether it is in linkage disequilibrium with another functional variant requires determination. Moreover, functional effects may depend upon cell type. For example, a variant in the upstream promoter region of the 5-HT1A receptor has been associated with impaired regulation by NUDR/Deaf-1, major depression (Lemonde et al, 2003), and altered sensitivity to an acute challenge with a 5-HT1A receptor agonist (Lesch and Gutknecht, 2004). However, the genetic influence on expression may differ between presynaptic and post-synaptic cells in the raphe nucleus (Lemonde et al, 2003). Strategies for assessing intra-gene epistasis are also needed. For example, within the dopamine transporter (DAT), particular combinations of polymorphisms, both upstream and downstream, may interact to influence DAT expression (Greenwood and Kelsoe, 2003).

Future directions: Late-life depression has many characteristics that potentially distinguish it from earlier onset depression. Included are the numerous medical, inflammatory, and vascular co-morbidities, as well as the potential relationship to dementia. Changes in receptor levels and mRNA expression patterns with aging may also result in differences from midlife depression, as well as differential sensitivity to pharmacologic agents. These differences provide challenges in extrapolating results of genetic studies using younger adults to older subjects. However, these differences may also provide the opportu- 
nity to understand more fully the etiology of depression and its consequences.

Additionally, although cross-sectional studies are informative, prospective longitudinal designs may ultimately be necessary for answering causal questions. Geriatric depression represents a unique opportunity for the conduct of prospective studies of specified depression subtypes and possibly for characterizing patients before the onset of depression. For example, vulnerability factors that may place euthymic individuals at high risk include loss of spouse (Vinkers et al, 2004), caregiver burden (Gallagher et al, 1989; Schulz et al, 1995), medical comorbidity (Cole and Dendukuri, 2003), cancer (Illman et al, 2005), and stroke (Antai-Otong, 2004). Another example is interferoninduced depression, in which many euthymic patients develop psychiatric symptoms including depression following the initiation of treatment (Valentine et al, 1998; Musselman et al, 2001). Longitudinal studies of these 'atrisk' populations may help inform how genetic vulnerability and resilience mechanistically influence the onset and development of depression. Relatedly, the interaction of genes and environment will be enhanced by studies that are focused on specific populations that are exposed to potential depressogenic triggers.

Guided by differences in patterns of drug response in the geriatric population (Lotrich and Pollock, 2005a), as well as medical triggers (eg, cardiac disease, menopause) of depression, other biologically plausible candidates for further investigation include the dopamine system, NMDA receptor subunits (eg, NR1), apolipoprotein E, vasopression and angiotensin receptors, inflammatory cytokine receptors (eg, TNF- $\alpha$ receptor), glucocorticoid receptors and chaperones (eg, FKBP5), nitric oxide (eg, nitric oxide synthetase), thyroid hormone receptors, estrogen, testosterone, Gproteins subunits (eg, $\alpha$ and $\beta 3$ subunits), adenylyl cyclases (eg, PKA regulatory subunit IIb), phospholipases (eg, PLC r1) phosphodiesterases isoforms (eg, phosphodiesterase 4), protein phosphatases (eg, $\mathrm{PP} 2 \mathrm{~A}$ and $\mathrm{PP} 2 \mathrm{~B}$ ), and regulatory proteins that influence intracellular transduction (eg, $\mathrm{A}$ kinase anchoring protein 79/150; Lotrich and Pollock 2005 b). Specifically guided by studies of menopause, a gene involved in estrogen metabolism has been implicated in perimenopausal depression (Kravitz et al, 2006). Similarly, the relative roles of these other systems in other potential subtypes of geriatric depression will require further evaluation.

The identification of multiple and varied 'at risk' elderly populations may provide useful cohorts to examine prospectively the interaction of genetic variation and various triggers of depression. Interactions between genetic risk and other potential sources of risk (including cardiovascular, inflammatory, psychosocial losses, early dementia) may provide meaningful insights into the pathophysiologic pathways leading to depression. Results from micro-array studies and from preliminary association analyses in midlife depression, have provided numerous plausible candidates for biologically guided future research. Moreover, although genetic studies in geriatric depression are only now beginning, statistical solutions to multiple testing, population stratification, and haplotype phasing are being addressed and will be feasible and appropriate to implement for the next generation of studies.
Potential causal mechanisms of genetic variation can be investigated using functional and structural neuroimaging. In this regard, the length polymorphism in the serotonin transporter promoter (5-HTTLPR) has been connected to glucocorticoids and cytokines (Glatz et al, 2003; Mossner et al, 2001), and this polymorphism has been associated with altered sensitivity to serotonergic challenges and functional differences in frontal-limbic pathways following both pharmacologic and affective challenges (eg, Smith et al, 2004; Hariri et al, 2002, 2005). These investigations are converging on an answer to the question of how this polymorphism may functionally influence the etiology of depression and the response to treatment. This single example illustrates how greater integration of genetics, neuroimaging, and pharmacologic challenges will be important in characterizing the functional consequences of other polymorphisms. In summary, genetics and its integration with other techniques appears to hold great promise in delineating the underlying pathways that influence the development, as well as the treatment of geriatric depression.

\section{Integrating Neuroimaging and Genetics}

Introduction. The majority of studies combining genetic and neuroimaging methods have focused on several genetic polymorphisms including the serotonin transporter promoter, apolipoprotein E (ApoE), catechol-O-methyltransferase (COMT), disrupted-in-schizophrenia (DISC1) and BDNF polymorphisms (as reviewed by Roffman et al, 2006; Meyer-Lindenberg and Weinberger, 2006; Hariri et al, 2006; Scarmeas and Stern 2005; Lehtovirta et al, 2000; Heinz and Smolka, 2006). The following summary of the literature will highlight the findings potentially relevant to the study of geriatric depression.

Summary of the literature. In normal subjects, the s allele of the 5HTTLPR gene has been associated with structural brain alterations such as reduced perigenual cingulate and amygdala gray matter volumes and functional uncoupling of the amygdala-prefrontal circuitry (Pezawas et al, 2005; Heinz et al, 2005). The s allele has also been associated with alterations in functional brain responses such as an increased amygdala activation response to fearful or anxiety-producing stimuli or a differentially lateralized cerebral metabolic response to serotonergic challenge (Hariri et al, 2002, 2005; Smith, et al, 2004). In patients with depression, the $l l$ genotype has been associated with smaller hippocampal volumes (Frodl et al, 2004). In older patients with the $l l$ genotype, later depression onset is associated with smaller hippocampal volumes, whereas earlier age of onset was associated with smaller volumes in individuals homozygous for the s allele (Taylor et al, 2005b). BDNF polymorphisms have also been associated with memory deficits and smaller hippocampal volumes (Egan et al, 2003; Hariri et al, 2003; Pezawas et al, 2004). Other genetic polymorphisms, such as COMT (Ho et al, 2005), DISC1 (Callicott et al, 2005), and myelination-related polymorphisms (Hakak et al, 2001) may also be related to structural alterations in gray and white matter. The COMT polymorphisms have been shown to be associated with differences in the processing of affective (greater amygdala 
response to unpleasant stimuli associated with the met158 allele) and cognitive tasks (a more focused activation response in working memory and attention control tasks associated with the val158 allele; as reviewed by Heinz and Smolka, 2006). At the present time, the transition from identifying a genetic polymorphisms related to a particular behavior and activation response and evaluating a medication targeted at the particular mechanism is best evidenced by the evaluating of the COMT inhibitor tolcopone for augmenting working memory and attentional control processes in normal subjects (Apud et al, 2006).

With respect to genetic and neuroimaging studies of monoamine receptor or transporter polymorphisms, the 5-HTTLPR and several dopamine (D2) polymorphisms have been the focus of study (Willeit et al, 2001; Heinz et al, 2000; Shioe et al, 2003). With respect to the 5-HTTLPR, an association between the polyporphisms and in vivo binding has not been shown in normal subjects (Shioe et al, 2003; Willeit et al, 2001), but an association has been shown in subjects who abuse alcohol (Heinz et al, 2000). With respect to the D2/D3 receptor, decreased D2/D3 receptor availability associated with the A1 allele of the TaqIA polymorphism has been reported in a study with $\left[{ }^{11} \mathrm{C}\right]$-raclopride (Hirvonen et al, 2004), as observed previously in a post-mortem autoradiographic study (Thompson et al, 1997). The variability in the magnitude of change in D2 receptor availability induced by smoking a cigarette was shown to be associated with COMT, the dopamine transporter and D4 receptor variable nucleotide tandem repeats and the D2 receptor Taq A1/A2 polymorphisms (Brody et al, 2006). The subjects with polymorphisms associated with low dopamine tone were related to greater changes in D2 receptor availability.

Vascular risk genes such as methylenetetrahydrofolate reductase (MTHFR) (Chen et al, 2005; Naismith et al, 2002) and potentially the 5HTTLPR (Ramasubbu, 2003) genotype may be associated with increased severity of cerebral hyperintense lesions and associated cognitive impairment (eg, psychomotor speed). With respect to the ApoE4 allele, Reiman et al $(1998,2001)$ initially demonstrated an association between the ApoE4 allele and low rates of glucose utilization, in addition to lower hippocampal volumes and worse long-term memory performance in cognitively normal subjects. These findings have been replicated by other groups and have been extended to aspects of pathophysiology associated with aging such as white matter structural integrity and hyperintensities and functional activation responses (as reviewed by Scarmeas and Stern, 2005).

Comment: Genetic associations of candidate genes in future neuroimaging experiments will involve the same challenges and caveats as those reviewed in the genetics section. In addition to these issues, there are several statistical issues with respect to appropriate statistical control for multiple testing and the fact that the sample sizes in neuroimaging studies are typically smaller than studies that involve less invasive and costly clinical outcome measures. In neuroimaging studies that involve drug challenges, attention to differences in drug exposure are critical (Lotrich et al, 2006). Moreover, although the majority of studies conducted thus far are cross-sectional, prospective longitudinal designs may ultimately be necessary for answering mechanistic and causal questions.

With respect to the structural and functional neuroimaging studies, intriguing observations have been reported with respect to several genetic polymorphisms as described above and the findings are generally internally consistent. With respect to the neurochemical imaging literature, the data are more limited. The available data suggest that dynamic measures of neurotransmitter function may be more informative with respect to understanding the functional neurochemical significance of genetic polymorphism than more static measures of neuroreceptor availability or number of binding sites. Thus, employing the dynamic imaging methods described in the neurochemical imaging section to combine acute pharmacologic intervention paradigms and measures of cerebral metabolism or blood flow or neuroreceptor availability represents a potentially important line of investigation and may lead to the elucidation of compensatory mechanisms.

As described in the genetics section, the identification of previously unsuspected genes is critical for advancing mechanistic and therapeutic research. Approaches to identifying potentially relevant genes include the study of animal models of aging, depression, and cognitive impairment, as well as the application of proteomic approaches to the study of post-mortem brain tissue of elderly subjects and patients with mood and neurodegenerative disorders (as reviewed by Vercauteren et al, 2004). The identification of new potentially relevant genes may also inform the development and evaluation of neurobiological targets for pharmacologic intervention studies and radiotracer development, as well as for therapeutics.

Future directions: The integration of genetic with neuroimaging methods may provide important information regarding the significance of specific genetic polymorphisms with respect to structural and functional neural circuitry and neurotransmitter pathways, as well as an understanding of between-subject variability in the neuroimaging measures and whether the same associations are observed in normal function and in disease. The integration of genetic and neuroimaging data may provide a better delineation of neurobiological subtypes of depression that might relate to different patterns of disease course or treatment response.

Several priorities for neuroimaging and genetics research have been articulated consistently in previous sections. These themes include the importance of understanding the neurobiological mechanism underlying heterogeneity in normal aging, depression vulnerability, medical comorbidity (cerebrovascular disease and neuroinflammation, in particular) variability in treatment response and the pathophysiology of cognitive impairment. In this section, the potential contribution of integrating genetics and neuroimaging methods to addressing these themes will be discussed.

With respect to the normal aging process, substantial variability in cognition, as well as in brain structure and the functional integrity of neural circuitry and neurochemical pathways has been observed. The evaluation of the 
neuroimaging measures relative to genetic polymorphisms is critical to identifying, which genes are associated with changes in the brain that result in cognitive impairment, and which genes are associated with compensatory processes identified by functional imaging methods to maintain cognitive function in the presence of brain structural and neurochemical alterations. The comparison of the associations between genes, cognition and brain structural and functional integrity in the normal aging process and the contrast with depressive disorders with onset across the lifespan could provide important neurobiological and therapeutic information. With respect to depression vulnerability, the study of depression in late life provides a unique opportunity to study vulnerability as the result of change in life circumstances and stress (eg, bereavement, caregiver burden, recovery from medical illness). The investigation of the neurochemical processes associated with genes related to depression risk may identify targets for more effective prevention and treatment strategies.

With respect to understanding variability in treatment response, the integration of genetic and neuroimaging measures may identify neurochemical subtypes of depression that may be associated with different speeds and rates of treatment response to different classes of antidepressant medications or to interventions, such as ECT, deep brain stimulation or transcranial magnetic stimulation. With respect to understanding mechanisms and developing interventions for cognitive impairment and the consequences of medical comorbidity (eg, hypertension, diabetes), serial neuroimaging studies could be used to monitor whether patterns of alterations are associated with specific genetic polymorphisms over time to determine whether the longitudinal course of geriatric depression could be altered in individuals depending on genotype with a particular class of agents (eg, antidepressant, cholinesterase inhibitors, diabetogenic agents or antihypertensives), who are potentially at greater risk for depression relapse and cognitive impairment.

For the goals of delineating the etiologies of depression, the mechanisms underlying vulnerability and resilience, the relationships between depression and other co-morbidities, and specific targets for individualized treatment and prevention, the inclusion of genetic analyses in neuroimaging is an exciting new direction.

\section{FUTURE DIRECTIONS}

Several directions for future research follow from the discussion above:

- The study of specific subject samples to ask questions about (1) the neurobiological differences in the early $v s$ late onset of depression and the impact of repeated depressive episodes across the life span; (2) the neurobiology of treatment-resistant depression, including psychotic depression; (3) neurobiological vulnerability markers and prevention strategies by studying such 'atrisk' subject samples, including patients with depression secondary to significant psychosocial stressors (bereavement, caregiver burden, as reviewed by Arean and
Reynolds, 2005) medical illness (cardiovascular disease, hip fracture or stroke), or medical interventions (interferon-induced symptoms, $\beta$-blocker-induced depressive symptoms).

- The application of genetic methods using candidate gene and micro-array strategies in patients and animal models (1) to characterize the genetic basis of treatment response variability and genetic polymorphisms related to specific cognitive deficits; (2) to identify the significance of genetic polymorphisms related to the structural neuroanatomic, functional and neurochemical alterations identified by neuroimaging studies (eg, white matter hyperintensities, hippocampal atrophy, decreased monoamine receptor binding, altered brain response to pharmacologic interventions); (3) to characterize genetic polymorphisms related to vulnerability to depression in the 'at-risk' samples as described above, and (4) to identify novel targets for radiotracer development and therapeutics.

- The development and application of affective and cognitive neuroscience approaches to characterize further the neural circuitry underlying deficits in speed of processing, affective processing, executive function, and memory using validated tasks combined with fMRI methods; (2) to characterize the domains of cognitive function that improve with antidepressant treatment, compared to those that remain impaired after remission of mood symptoms and, in addition, the cognitive domains that show decline longitudinally; (3) to evaluate the impact of novel acute and chronic pharmacologic interventions on the functional activation responses to inform the development of effective treatments to target these symptoms; and (4) to evaluate the variability in the functional activation response relative to structural brain changes and to genetic polymorphisms.

- The development and application of neurochemical imaging methods (1) to identify the acute and chronic neurochemical consequences of antidepressant treatment; (2) to characterize the neurochemical deficits that persist after antidepressant treatment and are related to residual mood and cognitive symptoms; (3) to develop and apply new radiotracers to target the same neurochemical systems, for which genetic polymorphisms have been shown to be related to treatment response variability and specific symptom domains; and (4) to understand the variability observed in the neurochemical measurements relative to relevant genetic polymorphisms for neurotransmitter metabolism, transporter or receptor availability.

- The directions for future research involving the integration of basic with clinical neuroscience research, include the following.

- The important area of post-mortem studies include (1) the further characterization of the pathophysiology of geriatric depression to inform the design of genetic, neuroimaging and neuropsychological studies; (2) the correlation of post-mortem data with cognitive and neuroimaging findings to understand the substrates of persistent mood and cognitive symptoms such as anhedonia and executive dysfunction; and (3) the correlation of postmortem and imaging findings to understand the underlying pathophysiology of volu- 
metric loss, white matter hyperintensities and neurochemical imaging findings.

- The development of animal models of geriatric depression has not been a focus of research, given the challenges in developing an animal model of depression and the practical constraints of studying aged animals. Models developed in younger animals could potentially be applied to aged animals (Cryan et al, 2005). Specific strains of rodents (eg, spontaneously hypertensive rats, cognitively impaired aged rats) could be used to mimic some aspects of pathophysiology. Knockout mice for the genetic targets that have been identified in the human studies as important to treatment response or cognitive impairment should be evaluated with respect to the functional or neurochemical response to pharmacologic agents for mood and cognitive symptoms. Conversely, the study of knockout mice that display similar behavioral or neurobiological features as geriatric depressed patients should be informative as well (Cryan and Holmes, 2005).

\section{CONCLUSION}

Understanding the complex nature of geriatric depression requires a translational and integrative approach. Neurobiological studies in geriatric depression represent unique opportunities for the identification of mechanisms of depression pathophysiology and vulnerability, which could potentially inform the development of intervention and prevention strategies. Such strategies may have relevance to the treatment of younger depressed patients, as well as to patients with depression secondary to other neuropsychiatric or medical illnesses (eg, Alzheimer's disease, Parkinson's disease, cerebrovascular disease), and to the development of integrative, conceptual models that could be applied to the study of other neuropsychiatric disorders. The translational research studies needed to address such neurobiologically complex questions require an integration of basic and clinical neuroscience approaches, including genetic and neuroimaging methods. Although the workshop and this report focus on unipolar major depression, the importance of research into psychotic depression, and bipolar disorder in late-life should be underscored. Two large scale multi-center trials in psychotic depression and bipolar disorder have been undertaken in the past few years, with an emphasis on the study of geriatric patients (Meyers et al, 2005; Young et al, 2004). The results of these clinical trials and the ancillary genetic and neuroimaging studies will provide important information to inform the design of neurobiological studies for these disabling disorders in the future. For hypothesis-driven, mechanistic research to evolve, continued interaction between investigators across disciplines (including geriatric psychiatry, genetics, neuropsychology, neuroimaging, and neuropathology) is critical.

\section{ACKNOWLEDGEMENTS}

This manuscript was generated from data presented and discussion at an NIMH sponsored workshop entitled 'Translational Research in Late-life Mood Disorders: Implications for Future Intervention and Prevention
Research.' The participants included Gwenn Smith (Department of Psychiatry and Behavioral Sciences, Albert Einstein College of Medicine), KRR Krishnan (Department of Psychiatry and Behavioral Sciences, Duke University; Co-Chairs), Jovier D Evans, National Institute of Mental Health, George Niederehe, National Institute of Mental Health, Victoria Arango (Department of Psychiatry, Division of Neuroscience, College of Physicians and Surgeons of Columbia University), Warren Taylor (Department of Psychiatry and Behavioral Sciences, Duke University), Anand Kumar (Department of Psychiatry and Behavioral Sciences, University of California at Los Angeles), Richard Shelton (Department of Psychiatry, Vanderbilt University), Susan Resnick (Intramural Program, National Institute on Aging), James Kennedy (Centre for Addiction and Mental Health, Department of Psychiatry, University of Toronto), Ramin Parsey (Department of Psychiatry, Division of Neuroscience, College of Physicians and Surgeons of Columbia University), Bruce Pollock (Department of Psychiatry, University of Toronto) Meryl Butters (Department of Psychiatry, University of Pittsburgh School of Medicine), David Steffens (Department of Psychiatry and Behavioral Sciences, Duke University), Eric Reiman (Department of Psychiatry and Behavioral Sciences, University of Arizona), Francis Lotrich (Department of Psychiatry, University of Pittsburgh School of Medicine), George Alexopoulos (Department of Psychiatry, Weil Medical College of Cornell University), Herb Harris (Jazz Pharmaceuticals, Incorporated), William Z Potter (Clinical Neuroscience, Merck Research Laboratories, Merck and Company, Inc.), C Anthony Altar (Psychiatric Genomics, Incorporated), Barry Lebowitz (Department of Psychiatry, University of California at San Diego).

Supported in part by National Institute of Health: K02 MH01621 (GSS), RO1 MH064823 (GSS), K23 MH074818, (FGD), K23 MH65939 (WDT), K23 MH074012 (FEL), and NARSAD (GSS).

The views expressed in this paper are those of the authors and should not be construed as official or as reflecting those of the NIMH, NIH, or Federal Government.

\section{REFERENCES}

Adler CM, DelBello MP, Strakowski SM (2006). Brain network dysfunction in bipolar disorder. CNS Spectr 11: 312-320.

Agren H, Reibring L (1994). PET studies of presynaptic monoamine metabolism in depressed patients and healthy volunteers. Pharmacopsychiatry 27: 2-6.

Agren H, Reibring L, Hartvig P, Tedroff J, Bjurling P, Hornfeldt K et al (1991). Low brain uptake of L- $\left[{ }^{11} \mathrm{C}\right] 5$-hydroxytryptophan in major depression: a positron emission tomography study on patients and healthy volunteers. Acta Psychiatr Scand 83: 449-455.

Aizenstein H, Butters MA, Cochran JL, Zmuda MD, Stenger VA, Becker JT (2005a). Prefrontal and Anterior Cingulate Cortex Functioning during Cognitive Control in Late-Life Depression. Presented at American Association of Geriatric Psychiatry Meeting. Lippincott Williams \& Wilkins: San Diego, CA.

Aizenstein HJ, Butters MA, Figurski JL, Stenger VA, Reynolds III CF, Carter CS (2005b). Prefrontal and striatal activation during sequence learning in geriatric depression. Biol Psychiatry 58 290-296. 
Alexopoulos GS (2002). Frontostriatal and limbic dysfunction in late-life depression. Am J Geriatr Psychiatry 10: 687-695.

Alexopoulos GS (2005). Depression in the elderly. Lancet 365: 1961-1970.

Alexopoulos GS, Kiosses DN, Choi SJ, Murphy CF, Lim KO (2002). Frontal white matter microstructure and treatment response of late-life depression: a preliminary study. Am J Psychiatry 159: 1929-1932.

Alexopoulos GS, Meyers BS, Young RC, Campbell S, Silbersweig D, Charlson M (1997a). Vascular depression hypothesis. Arch Gen Psychiatry 54: 915-922.

Alexopoulos GS, Meyers BS, Young RC, Kakuma T, Feder M, Einhorn A et al (1996a). Recovery in geriatric depression. Arch Gen Psychiatry 53: 305-312.

Alexopoulos GS, Meyers BS, Young RC, Kakuma T, Silbersweig D, Charlson M (1997b). Clinically defined vascular depression. Am J Psychiatry 154: 562-565.

Alexopoulos GS, Vrontou C, Kakuma T, Meyers BS, Young RC, Klausner E et al (1996b). Disability in geriatric depression. Am J Psychiatry 153: 877-885.

Alfonso J, Pollevick GD, Van Der Hart MG, Flugge G, Fuchs E, Frasch AC (2004). Identification of genes regulated by chronic psychosocial stress and antidepressant treatment in the hippocampus. Eur J Neurosci 19: 659-666.

Altar CA, Laeng P, Jurata LW, Brockman JA, Lemire A, Bullard J et al (2004). Electroconvulsive seizures regulate gene expression of distinct neurotrophic signaling pathways. J Neurosci 24: 2667-2677.

Altshuler D, Brooks LD, Chakravati A, Collins FS, Daly MJ, Donnelly P (2005). A haplotype map of the human genome. Nature 437: 1299-1320.

Anand A, Verhoeff P, Seneca N, Zoghbi SS, Seibyl JP, Charney DS et al (2000). Brain SPECT imaging of amphetamine-induced dopamine release in euthymic bipolar disorder patients. $A m \mathrm{~J}$ Psychiatry 157: 1108-1114.

Antai-Otong D (2004). Poststroke depression: psychopharmacological considerations. Perspect Psychiatr Care 40: 167-170.

Apud JA, Mattay V, Chen J, Kolachana BS, Callicott JH, Rasetti R et al (2006). Tolcapone improves cognition and cortical information processing in normal human subjects. Neuropsychopharmacology (E-pub ahead of print, 25 October 2006).

Arango V, Underwood MD, Mann JJ (2002). Serotonin brain circuits involved in major depression and suicide. Prog Brain Res 136: 443-453.

Arean PA, Reynolds III CF (2005). The impact of psychosocial factors on late-life depression. Biol Psychiatry 58: 277-282.

Arfken CL, Lichtenberg PA, Tancer ME (1999). Cognitive impairment and depression predict mortality in medically ill older adults. J Gerontol A Biol Sci Med Sci 54: M152-M156.

Arias B, Catalan R, Gasto C, Gutierrez B, Fananas L (2005). Evidence for a combined genetic effect of the 5-HT(1A) receptor and serotonin transporter genes in the clinical outcome of major depressive patients treated with citalopram. J Psychopharmacol 19: $166-172$.

Ashtari M, Greenwald BS, Kramer-Ginsberg E, Hu J, Wu H, Patel $M$ et al (1999). Hippocampal/amygdala volumes in geriatric depression. Psychol Med 29: 629-638.

Ballmaier M, Toga AW, Blanton RE, Sowell ER, Lavretsky H, Peterson J et al (2004). Anterior cingulate, gyrus rectus, and orbitofrontal abnormalities in elderly depressed patients: an MRI-based parcellation of the prefrontal cortex. Am J Psychiatry 161: 99-108.

Bell-McGinty S, Butters MA, Meltzer CC, Greer PJ, Reynolds III CF, Becker JT (2002). Brain morphometric abnormalities in geriatric depression: long-term neurobiological effects of illness duration. Am J Psychiatry 159: 1424-1427.

Binder EB, Holsboer F (2006). Pharmacogenomics and antidepressant drugs. Ann Med 38: 82-94.
Binder EB, Salyakina D, Lichtner P, Wochnik GM, Ising M, Putz B et al (2004). Polymorphisms in FKBP5 are associated with increased recurrence of depressive episodes and rapid response to antidepressant treatment. Nat Genet 36: 1319-1325.

Bremner JD, Vythilingam M, Vermetten E, Nazeer A, Adil J, Khan $S$ et al (2002). Reduced volume of orbitofrontal cortex in major depression. Biol Psychiatry 51: 273-279.

Brody AL, Mandelkern MA, Olmstead RE, Scheibal D, Hahn E, Shiraga $S$ et al (2006). Gene variants of brain dopamine pathways and smoking-induced dopamine release in the ventral caudate/nucleus accumbens. Arch Gen Psychiatry 63: 808-816.

Brown SM, Peet E, Manuck SB, Williamson DE, Dahl RE, Ferrell RE et al (2005). A regulatory variant of the human tryptophan hydroxylase- 2 gene biases amygdala reactivity. Mol Psychiatry 10: $805,884-888$.

Bruce ML, Leaf PJ (1989). Psychiatric disorders and 15-month mortality in a community sample of older adults. Am J Public Health 79: 727-730.

Bunney WE, Bunney BG, Vawter MP, Tomita H, Li J, Evans SJ et al (2003). Microarray technology: a review of new strategies to discover candidate vulnerability genes in psychiatric disorders. Am J Psychiatry 160: 657-666.

Butters MA, Becker JT, Nebes RD, Zmuda MD, Mulsant BH, Pollock BG et al (2000). Changes in cognitive functioning following treatment of late-life depression. Am J Psychiatry 157: 1949-1954.

Butters MA, Bhalla RK, Mulsant BH, Mazumdar S, Houck PR, Begley AE et al (2004). Executive functioning, illness course, and relapse/recurrence in continuation and maintenance treatment of late-life depression: is there a relationship? Am J Geriatr Psychiatry 12: 387-394.

Cabeza R, Anderson ND, Houle S, Mangels JA, Nyberg L (2000). Age-related differences in neural activity during item and temporal-order memory retrieval: a positron emission tomography study. J Cogn Neurosci 12: 197-206.

Cabeza R, Anderson ND, Locantore JK, McIntosh AR (2002). Aging gracefully: compensatory brain activity in high-performing older adults. Neuroimage 17: 1394-1402.

Cabeza R, Daselaar SM, Dolcos F, Prince SE, Budde M, Nyberg L (2004). Task-independent and task-specific age effects on brain activity during working memory, visual attention and episodic retrieval. Cereb Cortex 14: 364-375.

Callicott JH, Straub RE, Pezawas L, Egan MF, Mattay VS, Hariri AR et al (2005). Variation in DISC1 affects hippocampal structure and function and increases risk for schizophrenia. Proc Natl Acad Sci USA 102: 8627-8632.

Canli T, Cooney RE, Goldin P, Shah M, Sivers H, Thomason ME et al (2005). Amygdala reactivity to emotional faces predicts improvement in major depression. Neuroreport 16: 1267-1270.

Canli T, Sivers H, Thomason ME, Whitfield-Gabrieli S, Gabrieli JD, Gotlib IH (2004). Brain activation to emotional words in depressed vs healthy subjects. Neuroreport 15: 2585-2588.

Caspi A, Sugden K, Moffitt TE, Taylor A, Craig IW, Harrington H et al (2003). Influence of life stress on depression: moderation by a polymorphism in the 5-HTT gene. Science 301: 386-389.

Chen B, Wang JF, Sun X, Young LT (2003). Regulation of GAP-43 expression by chronic desipramine treatment in rat cultured hippocampal cells. Biol Psychiatry 53: 530-537.

Chen CS, Tsai JC, Tsang HY, Kuo YT, Lin HF, Chiang IC et al (2005). Homocysteine levels, MTHFR C677 T genotype, and MRI Hyperintensities in late-onset major depressive disorder. Am J Geriatr Psychiatry 13: 869-875.

Cole MG, Dendukuri N (2003). Risk factors for depression among elderly community subjects: a systematic review and metaanalysis. Am J Psychiatry 160: 1147-1156.

Conwell Y, Duberstein PR, Cox C, Herrmann JH, Forbes NT, Caine ED (1996). Relationships of age and axis I diagnoses in victims of 
completed suicide: a psychological autopsy study. $A m \mathrm{~J}$ Psychiatry 153: 1001-1008.

Craig DW, Stephan DA (2005). Applications of whole-genome high-density SNP genotyping. Expert Rev Mol Diagn 5: 159-170.

Craddock N, Forty L (2006). Genetics of affective (mood) disorders. EJHG 14: 660-668.

Cryan JF, Holmes A (2005). The ascent of mouse: advances in modelling human depression and anxiety. Nat Rev Drug Discov 4: 775-790.

Cryan JF, Valentino RJ, Lucki I (2005). Assessing substrates underlying the behavioral effects of antidepressants using the modified rat forced swimming test. Neurosci Biobehav Rev 29: 547-569.

Davidson RJ, Irwin W, Anderle MJ, Kalin NH (2003). The neural substrates of affective processing in depressed patients treated with venlafaxine. Am J Psychiatry 160: 64-75.

de Asis JM, Stern E, Alexopoulos GS, Pan H, Van Gorp W, Blumberg $\mathrm{H}$ et al (2001). Hippocampal and anterior cingulate activation deficits in patients with geriatric depression. Am J Psychiatry 158: 1321-1323.

DeKosky ST, Ikonomovic MD, Styren SD, Beckett L, Wisniewski S, Bennett DA et al (2002). Upregulation of choline acetyltransferase activity in hippocampus and frontal cortex of elderly subjects with mild cognitive impairment. Ann Neurol 51: 145-155.

Dew MA, Reynolds III CF, Houck PR, Hall M, Buysse DJ, Frank E et al (1997). Temporal profiles of the course of depression during treatment. Predictors of pathways toward recovery in the elderly. Arch Gen Psychiatry 54: 1016-1024.

Dewey SL, Smith GS, Logan J, Brodie JD, Fowler JS, Wolf AP (1993). Striatal binding of the PET ligand ${ }^{11} \mathrm{C}$-raclopride is altered by drugs that modify synaptic dopamine levels. Synapse 13: $350-356$.

Drevets WC, Frank E, Price JC, Kupfer DJ, Holt D, Greer PJ et al (1999). PET imaging of serotonin 1A receptor binding in depression. Biol Psychiatry 46: 1375-1387.

Duman RS, Heninger GR, Nestler EJ (1997). A molecular and cellular theory of depression. Arch Gen Psychiatry 54: 597-606.

Egan MF, Kojima M, Callicott JH, Goldberg TE, Kolachana BS, Bertolino A et al (2003). The BDNF val66met polymorphism affects activity-dependent secretion of BDNF and human memory and hippocampal function. Cell 112: 257-269.

Ehm MG, Nelson MR, Spurr NK (2005). Guidelines for conducting and reporting whole genome/large-scale association studies. Hum Mol Genet 14: 2485-2488.

Elderkin-Thompson V, Kumar A, Bilker WB, Dunkin JJ, Mintz J, Moberg PJ et al (2003). Neuropsychological deficits among patients with late-onset minor and major depression. Arch Clin Neuropsychol 18: 529-549.

Elderkin-Thompson V, Kumar A, Mintz J, Boone K, Bahng E, Lavretsky H (2004). Executive dysfunction and visuospatial ability among depressed elders in a community setting. Arch Clin Neuropsychol 19: 597-611.

Elliott R, Rubinsztein JS, Sahakian BJ, Dolan RJ (2002). The neural basis of mood-congruent processing biases in depression. Arch Gen Psychiatry 59: 597-604.

Erraji-Benchekroun L, Underwood MD, Arango V, Galfalvy H, Pavlidis P, Smyrniotopoulos P et al (2005). Molecular aging in human prefrontal cortex is selective and continuous throughout adult life. Biol Psychiatry 57: 549-558.

Evans SJ, Choudary PV, Neal CR, Li JZ, Vawter MP, Tomita $\mathrm{H}$ et al (2004). Dysregulation of the fibroblast growth factor system in major depression. Proc Natl Acad Sci USA 101: 15506-15511.

Fan J, McCandliss BD, Sommer T, Raz A, Posner MI (2002). Testing the efficiency and independence of attentional networks. J Cogn Neurosci 14: 340-347.

Farde L, Nordstrom AL, Wiesel FA, Pauli S, Halldin C, Sedvall G (1992). Positron emission tomographic analysis of central D1 and D2 dopamine receptor occupancy in patients treated with classical neuroleptics and clozapine. Relation to extrapyramidal side effects. Arch Gen Psychiatry 49: 538-544.

Firbank MJ, Lloyd AJ, Ferrier N, O’Brien JT (2004). A volumetric study of MRI signal hyperintensities in late-life depression. Am J Geriatr Psychiatry 12: 606-612.

Flint AJ (1994). Epidemiology and comorbidity of anxiety disorders in the elderly. Am J Psychiatry 151: 640-649.

Flint AJ (1998). Management of anxiety in late-life. J Geriatr Psychiatry Neurol 11: 194-200.

Flint AJ, Rifat SL (1999). Recurrence of first-episode geriatric depression after discontinuation of maintenance antidepressants. Am J Psychiatry 156: 943-945.

Fowler JS, Ding YS, Volkow ND (2003). Radiotracers for positron emission tomography imaging. Semin Nucl Med 33: 14-27.

Frodl T, Meisenzahl EM, Zill P, Baghai T, Rujescu D, Leinsinger G et al (2004). Reduced hippocampal volumes associated with the long variant of the serotonin transporter polymorphism in major depression. Arch Gen Psychiatry 61: 177-183.

Fujikawa T, Yokota N, Muraoka M, Yamawaki S (1996). Response of patients with major depression and silent cerebral infarction to antidepressant drug therapy, with emphasis on central nervous system adverse reactions. Stroke 27: 2040-2042.

Gallagher D, Rose J, Rivera P, Lovett S, Thompson LW (1989). Prevalence of depression in family caregivers. Gerontologist 29: 449-456.

George AE, de Leon MJ, Gentes CI, Miller J, London E, Budzilovich GN et al (1986a). Leukoencephalopathy in normal and pathologic aging: 1. CT of brain lucencies. AJNR 7: 561-566.

George AE, de Leon MJ, Kalnin A, Rosner L, Goodgold A, Chase N (1986b). Leukoencephalopathy in normal and pathologic aging: 2. MRI of brain lucencies. AJNR 7: 567-570.

Gladkevich A, Kauffman HF, Korf J (2004). Lymphocytes as a neural probe: potential for studying psychiatric disorders. Prog Neuropsychopharmacol Biol Psychiatry 28: 559-576.

Glaser R, Robles TF, Sheridan J, Malarkey WB, Kiecolt-Glaser JK (2003). Mild depressive symptoms are associated with amplified and prolonged inflammatory responses after influenza virus vaccination in older adults. Arch Gen Psychiatry 60: 1009-1014.

Glatz K, Mossner R, Heils A, Lesch KP (2003). Glucocorticoidregulated human serotonin transporter (5-HTT) expression is modulated by the 5-HTT gene-promotor-linked polymorphic region. J Neurochem 86: 1072-1078.

Greenwald BS, Kramer-Ginsberg E, Krishnan KR, Ashtari M, Auerbach C, Patel M (1998). Neuroanatomic localization of magnetic resonance imaging signal hyperintensities in geriatric depression. Stroke 29: 613-617.

Greenwald BS, Kramer-Ginsberg E, Krishnan RR, Ashtari M, Aupperle PM, Patel M (1996). MRI signal hyperintensities in geriatric depression. Am J Psychiatry 153: 1212-1215.

Greenwood TA, Kelsoe JR (2003). Promoter and intronic variants affect the transcriptional regulation of the human dopamine transporter gene. Genomics 82: 511-520.

Gron G, Bittner D, Schmitz B, Wunderlich AP, Riepe MW (2002). Subjective memory complaints: objective neural markers in patients with Alzheimer's disease and major depressive disorder. Ann Neurol 51: 491-498.

Groom GN, Junck L, Foster NL, Frey KA, Kuhl DE (1995). PET of peripheral benzodiazepine binding sites in the microgliosis of Alzheimer's disease. J Nucl Med 36: 2207-2210.

Gunning-Dixon FM, Gur RC, Perkins AC, Schroeder L, Turner T, Turetsky BI et al (2003). Age-related differences in brain activation during emotional face processing. Neurobiol Aging 24: $285-295$.

Gunning-Dixon FM, Hoptman MJ, D K, Sangoi R, Mack D, Alexopoulos GS (2005). Abnormal frontolimbic activation in late-life. Poster presented at the 5th Annual International College Geriatric Psychoneuropharmacology Meeting Pittsburgh, PA, November 2-5, 2005. 
Hakak Y, Walker JR, Li C, Wong WH, Davis KL, Buxbaum JD et al (2001). Genome-wide expression analysis reveals dysregulation of myelination-related genes in chronic schizophrenia. Proc Natl Acad Sci USA 98: 4746-4751.

Hariri AR, Drabant EM, Munoz KE, Kolachana BS, Mattay VS, Egan MF et al (2005). A susceptibility gene for affective disorders and the response of the human amygdala. Arch Gen Psychiatry 62: $146-152$

Hariri AR, Drabant EM, Weinberger DR (2006). Imaging genetics: perspectives from studies of genetically driven variation in serotonin function and corticolimbic affective processing. Biol Psychiatry 59: 888-897.

Hariri AR, Goldberg TE, Mattay VS, Kolachana BS, Callicott JH, Egan MF et al (2003). Brain-derived neurotrophic factor val66met polymorphism affects human memory-related hippocampal activity and predicts memory performance. J Neurosci 23: 6690-6694.

Hariri AR, Mattay VS, Tessitore A, Kolachana B, Fera F, Goldman $\mathrm{D}$ et al (2002). Serotonin transporter genetic variation and the response of the human amygdala. Science 297: 400-403.

Hattori E, Liu C, Zhu H, Gershon ES (2005). Genetic tests of biologic systems in affective disorders. Mol Psychiatry 10: 719-740.

Heinz A, Braus DF, Smolka MN, Wrase J, Puls I, Hermann D et al (2005). Amygdala-prefrontal coupling depends on a genetic variation of the serotonin transporter. Nat Neurosci 8: 20-21.

Heinz A, Jones DW, Mazzanti C, Goldman D, Ragan P, Hommer D et al (2000). A relationship between serotonin transporter genotype and in vivo protein expression and alcohol neurotoxicity. Biol Psychiatry 47: 643-649.

Heinz A, Smolka MN (2006). The effects of catechol Omethyltransferase genotype on brain activation elicited by affective stimuli and cognitive tasks. Rev Neurosci 17: 359-367.

Henriksson MM, Marttunen MJ, Isometsa ET, Heikkinen ME, Aro HM, Kuoppasalmi KI et al (1995). Mental disorders in elderly suicide. Int Psychogeriatr 7: 275-286.

Hickie I, Scott E, Mitchell P, Wilhelm K, Austin MP, Bennett B (1995). Subcortical hyperintensities on magnetic resonance imaging: clinical correlates and prognostic significance in patients with severe depression. Biol Psychiatry 37: 151-160.

Hirvonen M, Laakso A, Nagren K, Rinne JO, Pohjalainen T, Hietala $\mathrm{J}$ (2004). C957T polymorphism of the dopamine D2 receptor (DRD2) gene affects striatal DRD2 availability in vivo. Mol Psychiatry 9: 1060-1061.

Ho BC, Wassink TH, O'Leary DS, Sheffield VC, Andreasen NC (2005). Val158Met gene polymorphism in schizophrenia: working memory, frontal lobe MRI morphology and frontal cerebral blood flow. Mol Psychiatry 10: 229, 287-298.

Hume S, Hirani E, Opacka-Juffry J, Myers R, Townsend C, Pike V et al (2001). Effect of 5-HT on binding of [(11)C] WAY 100635 to 5 -HT(IA) receptors in rat brain, assessed using in vivo microdialysis nd PET after fenfluramine. Synapse 41: 150-159.

Iidaka T, Okada T, Murata T, Omori M, Kosaka H, Sadato N et al (2002). Age-related differences in the medial temporal lobe responses to emotional faces as revealed by fMRI. Hippocampus 12: $352-362$.

Illman J, Corringham R, Robinson Jr D, Davis HM, Rossi JF, Cella $\mathrm{D}$ et al (2005). Are inflammatory cytokines the common link between cancer-associated cachexia and depression? J Support Oncol 3: 37-50.

Insel TR, Quirion R (2005). Psychiatry as a clinical neuroscience discipline. JAMA 294: 2221-2224.

Jacobs BL, Praag H, Gage FH (2000). Adult brain neurogenesis and psychiatry: a novel theory of depression. Mol Psychiatry 5: 262-269.

Jorm AF, van Duijn CM, Chandra V, Fratiglioni L, Graves AB, Heyman A et al (1991). Psychiatric history and related exposures as risk factors for Alzheimer's disease: a collaborative re-analysis of case-control studies. EURODEM Risk Factors Research Group. Int J Epidemiol 20(Suppl 2): S43-S47.

Klunk WE, Engler H, Nordberg A, Wang Y, Blomqvist G, Holt DP et al (2004). Imaging brain amyloid in Alzheimer's disease with Pittsburgh Compound-B. Ann Neurol 55: 306-319.

Koschack J, Irle E (2005). Small hippocampal size in cognitively normal subjects with coronary artery disease. Neurobiol Aging 26: $865-871$.

Kramer-Ginsberg E, Greenwald BS, Krishnan KR, Christiansen B, $\mathrm{Hu}$ J, Ashtari $\mathrm{M}$ et al (1999). Neuropsychological functioning and MRI signal hyperintensities in geriatric depression. Am J Psychiatry 156: 438-444.

Kravitz HM, Janssen I, Lotrich FE, Kado DM, Bromberger JT (2006). Sex steroid hormone gene polymorphisms and depressive symptoms in women at midlife. Am J Med 119(Suppl 1): S87-S93.

Krishnan KR (1993). Neuroanatomic substrates of depression in the elderly. J Geriatr Psychiatry Neurol 6: 39-58.

Krishnan KR (2002). Biological risk factors in late-life depression. Biol Psychiatry 52: 185-192.

Krishnan KR, Hays JC, Blazer DG (1997). MRI-defined vascular depression. Am J Psychiatry 154: 497-501.

Kuhl DE, Minoshima S, Frey KA, Foster NL, Kilbourn MR, Koeppe RA (2000). Limited donepezil inhibition of acetylcholinesterase measured with positron emission tomography in living Alzheimer cerebral cortex. Ann Neurol 48: 391-395.

Kumar A, Bilker W, Jin Z, Udupa J (2000). Atrophy and high intensity lesions: complementary neurobiological mechanisms in late-life major depression. Neuropsychopharmacology 22: 264-274.

Kumar A, Gupta RC, Albert Thomas M, Alger J, Wyckoff N, Hwang S (2004). Biophysical changes in normal-appearing white matter and subcortical nuclei in late-life major depression detected using magnetization transfer. Psychiatry Res 130: 131-140.

Kumar A, Jin Z, Bilker W, Udupa J, Gottlieb G (1998). Late-onset minor and major depression: early evidence for common neuroanatomical substrates detected by using MRI. Proc Natl Acad Sci USA 95: 7654-7658.

Kumar A, Mintz J, Bilker W, Gottlieb G (2002). Autonomous neurobiological pathways to late-life major depressive disorder: clinical and pathophysiological implications. Neuropsychopharmacology 26: 229-236.

Lai T, Payne ME, Byrum CE, Steffens DC, Krishnan KR (2000). Reduction of orbital frontal cortex volume in geriatric depression. Biol Psychiatry 48: 971-975.

Lamar M, Yousem DM, Resnick SM (2004). Age differences in orbitofrontal activation: an fMRI investigation of delayed match and nonmatch to sample. Neuroimage 21: 1368-1376.

Landgrebe J, Welzl G, Metz T, van Gaalen MM, Ropers H, Wurst W et al (2002). Molecular characterisation of antidepressant effects in the mouse brain using gene expression profiling. J Psychiatr Res 36: 119-129.

Lavretsky H, Kumar A (2001). Methylphenidate augmentation of citalopram in elderly depressed patients. Am J Geriatr Psychiatry 9: 298-303.

Lebowitz BD, Pearson JL, Schneider LS, Reynolds III CF, Alexopoulos GS, Bruce ML et al (1997). Diagnosis and treatment of depression in late-life. Consensus statement update. JAMA 278: 1186-1190.

Lee SH, Payne ME, Steffens DC, McQuoid DR, Lai TJ, Provenzale JM et al (2003). Subcortical lesion severity and orbitofrontal cortex volume in geriatric depression. Biol Psychiatry 54: $529-533$.

Lehtovirta M, Laakso MP, Frisoni GB, Soininen H (2000). How does the apolipoprotein $\mathrm{E}$ genotype modulate the brain in aging and in Alzheimer's disease? A review of neuroimaging studies. Neurobiol Aging 21: 293-300. 
Lemonde S, Turecki G, Bakish D, Du L, Hrdina PD, Bown CD et al (2003). Impaired repression at a 5-hydroxytryptamine $1 \mathrm{~A}$ receptor gene polymorphism associated with major depression and suicide. J Neurosci 23: 8788-8799.

Lenze EJ, Mulsant BH, Shear MK, Schulberg HC, Dew MA, Begley $\mathrm{AE}$ et al (2000). Comorbid anxiety disorders in depressed elderly patients. Am J Psychiatry 157: 722-728.

Lenze EJ, Munin MC, Ferrell RE, Pollock BG, Skidmore E, Lotrich F et al (2005). Association of the serotonin transporter gene-linked polymorphic region (5-HTTLPR) genotype with depression in elderly persons after hip fracture. Am J Geriatr Psychiatry 13: 428-432.

Leonardo ED, Hen R (2006). Genetics of affective and anxiety disorders. Annu Rev Psychol 57: 117-137.

Lesch KP, Bengel D, Heils A, Sabol SZ, Greenberg BD, Petri S et al (1996). Association of anxiety-related traits with a polymorphism in the serotonin transporter gene regulatory region. Science 274: 1527-1531.

Lesch KP, Gutknecht L (2004). Focus on The 5-HT1A receptor: emerging role of a gene regulatory variant in psychopathology and pharmacogenetics. Int J Neuropsychopharmacol 7: 381-385.

Lesch KP, Gutknecht L (2005). Pharmacogenetics of the serotonin transporter. Prog Neuropsychopharmacol Biol Psychiatry 29: 1062-1073.

Lesser IM, Boone KB, Mehringer CM, Wohl MA, Miller BL, Berman NG (1996). Cognition and white matter hyperintensities in older depressed patients. Am J Psychiatry 153: 1280-1287.

Leuchter AF, Cook IA, Uijtdehaage SH, Dunkin J, Lufkin RB, Anderson-Hanley C et al (1997). Brain structure and function and the outcomes of treatment for depression. J Clin Psychiatry 58(Suppl 16): 22-31.

Levinson DF (2006). The genetics of depression: a review. Biol Psychiatry 60: 84-92 (E-pub 21 November 2005).

Little JT, Reynolds III CF, Dew MA, Frank E, Begley AE, Miller MD et al (1998). How common is resistance to treatment in recurrent, nonpsychotic geriatric depression? Am J Psychiatry 155: $1035-1038$

Lockwood KA, Alexopoulos GS, Kakuma T, Van Gorp WG (2000). Subtypes of cognitive impairment in depressed older adults. Am J Geriatr Psychiatry 8: 201-208.

Lockwood KA, Alexopoulos GS, van Gorp WG (2002). Executive dysfunction in geriatric depression. Am J Psychiatry 159: 1119-1126.

Lotrich FE, Bies RR, Smith GS, Pollock BG (2006). Relevance of assessing drug concentration exposure in pharmacogenetic and imaging studies. J Psychopharmacol 20: 33-40.

Lotrich FE, Pollock BG (2004). Meta-analysis of serotonin transporter polymorphisms and affective disorders. Psychiatr Genet 14: 121-129.

Lotrich FE, Pollock BG (2005a). Candidate genes for antidepressant response to selective serotonin reuptake inhibitors. Neuropsychiatric Dis Treat 1: 17-35.

Lotrich FE, Pollock BG (2005b). Aging and clinical pharmacology: implications for antidepressants. J Clin Pharmacol 45: $1106-1122$.

Lukiw WJ (2004). Gene expression profiling in fetal, aged, and Alzheimer hippocampus: a continuum of stress-related signaling. Neurochem Res 29: 1287-1297.

Macfall JR, Taylor WD, Rex DE, Pieper S, Payne ME, McQuoid DR et al (2005). Lobar distribution of lesion volumes in late-life depression: The Biomedical Informatics Research Network (BIRN). Neuropsychopharmacology 31: 1500-1507.

Malison RT, Price LH, Berman R, van Dyck CH, Pelton GH, Carpenter L et al (1998). Reduced brain serotonin transporter availability in major depression as measured by [123I]-2 beta-carbomethoxy-3 beta-(4-iodophenyl)tropane and single photon emission computed tomography. Biol Psychiatry 44: 1090-1098.
Mann JJ (1998). Neurobiological correlates of the antidepressant action of electroconvulsive therapy. J ECT 14: 172-180.

Mayberg HS (2003). Modulating dysfunctional limbic-cortical circuits in depression: towards development of brain-based algorithms for diagnosis and optimised treatment. Br Med Bull 65: 193-207.

Mazure CM, Maciejewski PK, Jacobs SC, Bruce ML (2002). Stressful life events interacting with cognitive/personality styles to predict late-onset major depression. Am J Geriatr Psychiatry 10: 297-304.

Meltzer CC, Price JC, Mathis CA, Greer PJ, Cantwell MN, Houck PR et al (1999). PET imaging of serotonin type $2 \mathrm{~A}$ receptors in latelife neuropsychiatric disorders. Am J Psychiatry 156: 1871-1878.

Meyer JH, Cho R, Kennedy S, Kapur S (1999). The effects of single dose nefazodone and paroxetine upon 5-HT2A binding potential in humans using [18F]-setoperone PET. Psychopharmacology (Berl) 144: 279-281.

Meyer JH, Ginovart N, Boovariwala A, Sagrati S, Hussey D, Garcia A et al (2006). Elevated monoamine oxidase a levels in the brain: an explanation for the monoamine imbalance of major depression. Arch Gen Psychiatry 63: 1209-1216.

Meyer JH, Houle S, Sagrati S, Carella A, Hussey DF, Ginovart N et al (2004). Brain serotonin transporter binding potential measured with carbon 11-labeled DASB positron emission tomography: effects of major depressive episodes and severity of dysfunctional attitudes. Arch Gen Psychiatry 61: 1271-1279.

Meyer JH, Kapur S, Eisfeld B, Brown GM, Houle S, DaSilva J et al (2001a). The effect of paroxetine on 5-HT(2A) receptors in depression: an [(18)F]setoperone PET imaging study. Am J Psychiatry 158: 78-85.

Meyer JH, Kapur S, Houle S, DaSilva J, Owczarek B, Brown GM et al (1999b). Prefrontal cortex 5-HT2 receptors in depression: an $[18 \mathrm{~F}]$ setoperone PET imaging study. Am J Psychiatry 156: 1029-1034

Meyer JH, Kruger S, Wilson AA, Christensen BK, Goulding VS, Schaffer A et al (2001b). Lower dopamine transporter binding potential in striatum during depression. Neuroreport 12: 41214125 .

Meyer JH, McMain S, Kennedy SH, Korman L, Brown GM, DaSilva JN et al (2003). Dysfunctional attitudes and 5-HT2 receptors during depression and self-harm. Am J Psychiatry 160: 90-99.

Meyer JH, Wilson AA, Ginovart N, Goulding V, Hussey D, Hood K et al (2001c). Occupancy of serotonin transporters by paroxetine and citalopram during treatment of depression: a [(11)C]DASB PET imaging study. Am J Psychiatry 158: 1843-1849.

Meyer-Lindenberg A, Weinberger DR (2006). Intermediate phenotypes and genetic mechanisms of psychiatric disorders. Nat Rev Neurosci 7: 818-827.

Meyers BS, Bruce ML (1998). The depression-dementia conundrum: integrating clinical and epidemiological perspectives. Arch Gen Psychiatry 55: 1082-1083.

Meyers BS, Flint A, Alastair J, Mulsant BH, Rothschild AJ (2005). The NIMH Stop-PD Trial: Background and Design Choices. Poster presented at the 5th Annual International College Geriatric Psychoneuropharmacology Meeting, Pittsburgh, PA, November 2-5, 2005.

Mossner R, Daniel S, Schmitt A, Albert D, Lesch KP (2001). Modulation of serotonin transporter function by interleukin-4. Life Sci 68: 873-880.

Murphy CF, Alexopoulos GS (2006). Attention network dysfunction and treatment response of geriatric depression. J Clin Exp Neuropsychol 28: 96-100.

Murphy Jr GM, Hollander SB, Rodrigues HE, Kremer C, Schatzberg AF (2004). Effects of the serotonin transporter gene promoter polymorphism on mirtazapine and paroxetine efficacy and adverse events in geriatric major depression. Arch Gen Psychiatry 61: 1163-1169. 
Musselman DL, Lawson DH, Gumnick JF, Manatunga AK, Penna S, Goodkin RS et al (2001). Paroxetine for the prevention of depression induced by high-dose interferon alfa. $N$ Engl J Med 344: 961-966.

Naismith S, Hickie I, Ward PB, Turner K, Scott E, Little C et al (2002). Caudate nucleus volumes and genetic determinants of homocysteine metabolism in the prediction of psychomotor speed in older persons with depression. Am J Psychiatry 159: 2096-2098.

Narushima K, Kosier JT, Robinson RG (2002). Preventing poststroke depression: a 12-week double-blind randomized treatment trial and 21-month follow-up. J Nerv Ment Dis 190: 296-303.

Nebes RD, Butters MA, Houck PR, Zmuda MD, Aizenstein H, Pollock BG et al (2001). Dual-task performance in depressed geriatric patients. Psychiatry Res 102: 139-151.

Nebes RD, Pollock BG, Houck PR, Butters MA, Mulsant BH, Zmuda MD et al (2003). Persistence of cognitive impairment in geriatric patients following antidepressant treatment: a randomized, double-blind clinical trial with nortriptyline and paroxetine. J Psychiatr Res 37: 99-108.

Nemeroff CB, Vale WW (2005). The neurobiology of depression: inroads to treatment and new drug discovery. J Clin Psychiatry 66(Suppl 7): 5-13.

Nielson KA, Langenecker SA, Garavan H (2002). Differences in the functional neuroanatomy of inhibitory control across the adult life span. Psychol Aging 17: 56-71.

Nielson KA, Langenecker SA, Ross TJ, Garavan H, Rao SM, Stein EA (2004). Comparability of functional MRI response in young and old during inhibition. Neuroreport 15: 129-133.

Nobuhara K, Okugawa G, Sugimoto T, Minami T, Tamagaki C, Takase $\mathrm{K}$ et al (2006). Frontal white matter anisotropy and symptom severity of late-life depression: a magnetic resonance diffusion tensor imaging study. J Neurol Neurosurg Psychiatry 77: $120-122$

O’Brien JT, Lloyd A, McKeith I, Gholkar A, Ferrier N (2004). A longitudinal study of hippocampal volume, cortisol levels, and cognition in older depressed subjects. Am J Psychiatry 161: 2081-2090.

O'Connor MK, Knapp R, Husain M, Rummans TA, Petrides G, Smith $\mathrm{G}$ et al (2001). The influence of age on the response of major depression to electroconvulsive therapy: a C.O.R.E. Report. Am J Geriatr Psychiatry 9: 382-390.

Paez-Pereda M (2005). New drug targets in the signaling pathways activated by antidepressants. Prog Neuro-Psychopharmacol Biol Psychiatry 29: 1010-1016.

Parsey RV, Oquendo MA, Ogden RT, Olvet DM, Simpson N, Huang YY et al (2006). Altered serotonin 1A binding in major depression: a [carbonyl-C-11]WAY100635 positron emission tomography study. Biol Psychiatry 59: 106-113.

Parsey RV, Oquendo MA, Zea-Ponce Y, Rodenhiser J, Kegeles LS, Pratap $\mathrm{M}$ et al (2001). Dopamine $\mathrm{D}(2)$ receptor availability and amphetamine-induced dopamine release in unipolar depression. Biol Psychiatry 50: 313-322.

Pezawas L, Meyer-Lindenberg A, Drabant EM, Verchinski BA, Munoz KE, Kolachana BS et al (2005). 5-HTTLPR polymorphism impacts human cingulate-amygdala interactions: a genetic susceptibility mechanism for depression. Nat Neurosci 8: 828-834.

Pezawas L, Verchinski BA, Mattay VS, Callicott JH, Kolachana BS, Straub RE et al (2004). The brain-derived neurotrophic factor val66met polymorphism and variation in human cortical morphology. J Neurosci 24: 10099-10102.

Pierpaoli C, Basser PJ (1996). Toward a quantitative assessment of diffusion anisotropy. Magn Reson Med 36: 893-906.

Pillay SS, Renshaw PF, Bonello CM, Lafer BC, Fava M, YurgelunTodd D (1998). A quantitative magnetic resonance imaging study of caudate and lenticular nucleus gray matter volume in primary unipolar major depression: relationship to treatment response and clinical severity. Psychiatry Res 84: 61-74.

Pollock BG, Ferrell RE, Mulsant BH, Mazumdar S, Miller M, Sweet RA et al (2000). Allelic variation in the serotonin transporter promoter affects onset of paroxetine treatment response in latelife depression. Neuropsychopharmacology 23: 587-590.

Posener JA, Wang L, Price JL, Gado MH, Province MA, Miller MI et al (2003). High-dimensional mapping of the hippocampus in depression. Am J Psychiatry 160: 83-89.

Rajkowska G, Miguel-Hidalgo JJ, Dubey P, Stockmeier CA, Krishnan KR (2005). Prominent reduction in pyramidal neurons density in the orbitofrontal cortex of elderly depressed patients. Biol Psychiatry 58: 297-306.

Ramasubbu R (2003). Serotonin transporter gene functional polymorphism: a plausible candidate gene for increased vascular risk in depression. Med Hypotheses 61: 36-44.

Reiman EM, Caselli RJ, Chen K, Alexander GE, Bandy D, Frost J (2001). Declining brain activity in cognitively normal apolipoprotein E epsilon 4 heterozygotes: a foundation for using positron emission tomography to efficiently test treatments to prevent Alzheimer's disease. Proc Natl Acad Sci USA 98: 33343339.

Reiman EM, Uecker A, Caselli RJ, Lewis S, Bandy D, de Leon MJ et al (1998). Hippocampal volumes in cognitively normal persons at genetic risk for Alzheimer's disease. Ann Neurol 44: 288-291.

Reynolds III CF, Dew MA, Frank E, Begley AE, Miller MD, Cornes C et al (1998). Effects of age at onset of first lifetime episode of recurrent major depression on treatment response and illness course in elderly patients. Am J Psychiatry 155: 795-799.

Reynolds III CF, Frank E, Dew MA, Houck PR, Miller M, Mazumdar S et al (1999). Treatment of 70(+)-year-olds with recurrent major depression. Excellent short-term but brittle long-term response. Am J Geriatr Psychiatry 7: 64-69.

Reynolds III CF, Frank E, Perel JM, Mazumdar S, Dew MA, Begley A et al (1996). High relapse rate after discontinuation of adjunctive medication for elderly patients with recurrent major depression. Am J Psychiatry 153: 1418-1422.

Ricciarelli R, d'Abramo C, Massone S, Marinari U, Pronzato M, Tabaton M (2004). Microarray analysis in Alzheimer's disease and normal aging. IUBMB Life 56: 349-354.

Roffman JL, Weiss AP, Goff DC, Rauch SL, Weinberger DR (2006). Neuroimaging-genetic paradigms: a new approach to investigate the pathophysiology and treatment of cognitive deficits in schizophrenia. Harv Rev Psychiatry 14: 78-91.

Rosa-Neto P, Diksic M, Okazawa H, Leyton M, Ghadirian N, Mzengeza $S$ et al (2004). Measurement of brain regional alpha$\left[{ }^{11} \mathrm{C}\right]$ methyl-L-tryptophan trapping as a measure of serotonin synthesis in medication-free patients with major depression. Arch Gen Psychiatry 61: 556-563.

Rose EJ, Simonotto E, Ebmeier KP (2006). Limbic over-activity in depression during preserved performance on the n-back task. Neuroimage 29: 203-215.

Rybakowski JK, Borkowska A, Czerski PM, Skibinska M, Hauser J (2003). Polymorphism of the brain-derived neurotrophic factor gene and performance on a cognitive prefrontal test in bipolar patients. Bipolar Disord 5: 468-472.

Sahakian BJ, Owen AM (1992). Computerized assessment in neuropsychiatry using CANTAB: discussion paper. $J$ R Soc Med 85: 399-402.

Sargent PA, Kjaer KH, Bench CJ, Rabiner EA, Messa C, Meyer J et al (2000). Brain serotonin1A receptor binding measured by positron emission tomography with $\left[{ }^{11} \mathrm{C}\right]$ WAY-100635: effects of depression and antidepressant treatment. Arch Gen Psychiatry 57: $174-180$.

Scarmeas N, Stern Y (2005). Imaging studies and APOE genotype in persons at risk for Alzheimer's disease. Curr Psychiatry Rep 8: 11-17. 
Schatzberg A, Garlow S, Nemeroff CB (2002). Molecular and cellular mechanisms in depression. In: (Series) Neuropsychopharmacology: The Fifth Generation of Progress. Lippincott Williams \& Wilkins: Philadelphia. pp 1039-1050.

Schildkraut JJ (1965). The catecholamine hypothesis of affective disorders: a review of supporting evidence. Am J Psychiat 122: 509-522.

Schinka JA, Busch RM, Robichaux-Keene N (2004). A metaanalysis of the association between the serotonin transporter gene polymorphism (5-HTTLPR) and trait anxiety. Mol Psychiatry 9: 197-202.

Schulz R, O’Brien AT, Bookwala J, Fleissner K (1995). Psychiatric and physical morbidity effects of dementia caregiving: prevalence, correlates, and causes. Gerontologist 35: 771-791.

Serretti A, Benedetti F, Zanardi R, Smeraldi E (2005). The influence of Serotonin Transporter Promoter Polymorphism (SERTPR) and other polymorphisms of the serotonin pathway on the efficacy of antidepressant treatments. Prog Neuropsychopharmacol Biol Psychiatry 29: 1074-1084.

Shear K, Frank E, Houck PR, Reynolds III CF (2005). Treatment of complicated grief: a randomized controlled trial. JAMA 293: 2601-2608.

Sheline YI, Gado MH, Kraemer HC (2003). Untreated depression and hippocampal volume loss. Am J Psychiatry 160: 1516-1518.

Sheline YI, Gado MH, Price JL (1998). Amygdala core nuclei volumes are decreased in recurrent major depression. Neuroreport 9: 2023-2028.

Sheline YI, Sanghavi M, Mintun MA, Gado MH (1999). Depression duration but not age predicts hippocampal volume loss in medically healthy women with recurrent major depression. I Neurosci 19: 5034-5043.

Sheline YI, Wang PW, Gado MH, Csernansky JG, Vannier MW (1996). Hippocampal atrophy in recurrent major depression. Proc Natl Acad Sci USA 93: 3908-3913.

Shioe K, Ichimiya T, Suhara T, Takano A, Sudo Y, Yasuno F et al (2003). No association between genotype of the promoter region of serotonin transporter gene and serotonin transporter binding in human brain measured by PET. Synapse 48: 184-188.

Sibille E, Arango V, Galfalvy HC, Pavlidis P, Erraji-Benchekroun L, Ellis SP et al (2004). Gene expression profiling of depression and suicide in human prefrontal cortex. Neuropsychopharmacology 29: $351-361$.

Simpson SW, Jackson A, Baldwin RC, Burns A (1997). 1997 IPA/Bayer Research Awards in psychogeriatrics. Subcortical hyperintensities in late-life depression: acute response to treatment and neuropsychological impairment. Int Psychogeriatr 9: $257-275$

Smith GS, Kramer E, Hermann CR, Goldberg S, Ma Y, Dhawan V (2000). Evaluation of citalopram as a pharmacologic intervention of the serotonin system. Biol Psychiat 47: S99.

Smith GS, Kramer E, Hermann CR, Goldberg S, Ma Y, Dhawan V et al (2002a). Acute and chronic effects of citalopram on cerebral glucose metabolism in geriatric depression. Am J Geriatr Psychiatry 10: 715-723.

Smith GS, Lotrich FE, Malhotra AK, Lee AT, Ma Y, Kramer E et al (2004). Effects of serotonin transporter promoter polymorphisms on serotonin function. Neuropsychopharmacology 29: $2226-2234$.

Smith GS, Ma Y, Dhawan V, Gunduz H, Carbon M, Kirshner M et al (2002b). Serotonin modulation of cerebral glucose metabolism measured with positron emission tomography (PET) in human subjects. Synapse 45: 105-112.

Smith GS, Reynolds III CF, Houck PR, Dew MA, Ma Y, Mulsant BH et al (2002c). Glucose metabolic response to total sleep deprivation, recovery sleep, and acute antidepressant treatment as functional neuroanatomic correlates of treatment outcome in geriatric depression. Am J Geriatr Psychiatry 10: $561-567$.
Smith GS, Reynolds III CF, Pollock B, Derbyshire S, Nofzinger E, Dew MA et al (1999). Cerebral glucose metabolic response to combined total sleep deprivation and antidepressant treatment in geriatric depression. Am J Psychiatry 156: 683-689.

Steffens DC, Byrum CE, McQuoid DR, Greenberg DL, Payne ME, Blitchington TF et al (2000). Hippocampal volume in geriatric depression. Biol Psychiatry 48: 301-309.

Steffens DC, Conway CR, Dombeck CB, Wagner HR, Tupler LA, Weiner RD (2001). Severity of subcortical gray matter hyperintensity predicts ECT response in geriatric depression. J Ect 17: 45-49.

Steffens DC, Payne ME, Greenberg DL, Byrum CE, Welsh-Bohmer KA, Wagner HR et al (2002). Hippocampal volume and incident dementia in geriatric depression. Am J Geriatr Psychiatry 10: $62-71$.

Strauss J, Barr CL, George CJ, King N, Shaikh S, Devlin B et al (2004). Association study of brain-derived neurotrophic factor in adults with a history of childhood onset mood disorder. Am J Med Genet B Neuropsychiatr Genet 131: 16-19.

Styner M, Lieberman JA, Pantazis D, Gerig G (2004). Boundary and medial shape analysis of the hippocampus in schizophrenia. Med Image Anal 8: 197-203.

Suhara T, Nakayama K, Inoue O, Fukuda H, Shimizu M, Mori A et al (1992). D1 dopamine receptor binding in mood disorders measured by positron emission tomography. Psychopharmacology (Berlin) 106: 14-18.

Surguladze S, Brammer MJ, Keedwell P, Giampietro V, Young AW, Travis MJ et al (2005). A differential pattern of neural response toward sad versus happy facial expressions in major depressive disorder. Biol Psychiatry 57: 201-209.

Sweet RA, Hamilton RL, Butters MA, Mulsant BH, Pollock BG, Lewis DA et al (2004). Neuropathologic correlates of late-onset major depression. Neuropsychopharmacology 29: 2242-2250.

Szuba MP, O'Reardon JP, Evans DL (2000). Physiological effects of electroconvulsive therapy and transcranial magnetic stimulation in major depression. Depress Anxiety 12: 170-177.

Taylor WD, MacFall JR, Payne ME, McQuoid DR, Provenzale JM, Steffens DC et al (2004). Late-life depression and microstructural abnormalities in dorsolateral prefrontal cortex white matter. Am J Psychiatry 161: 1293-1296.

Taylor WD, MacFall JR, Payne ME, McQuoid DR, Steffens DC, Provenzale JM et al (2005a). Greater MRI lesion volumes in elderly depressed subjects than in control subjects. Psychiatry Res 139: 1-7.

Taylor WD, Steffens DC, Payne ME, MacFall JR, Marchuk DA, Svenson IK et al (2005b). Influence of serotonin transporter promoter region polymorphisms on hippocampal volumes in late-life depression. Arch Gen Psychiatry 62: 537-544.

Tessitore A, Hariri AR, Fera F, Smith WG, Das S, Weinberger DR et al (2005). Functional changes in the activity of brain regions underlying emotion processing in the elderly. Psychiatry Res 139: 9-18.

Tew Jr JD, Mulsant BH, Haskett RF, Prudic J, Thase ME, Crowe RR et al (1999). Acute efficacy of ECT in the treatment of major depression in the old-old. Am J Psychiatry 156: 1865-1870.

Thomas AJ, Ferrier IN, Kalaria RN, Woodward SA, Ballard C, Oakley A et al (2000). Elevation in late-life depression of intercellular adhesion molecule-1 expression in the dorsolateral prefrontal cortex. Am J Psychiatry 157: 1682-1684.

Thomas AJ, O'Brien JT, Davis S, Ballard C, Barber R, Kalaria RN et al (2002). Ischemic basis for deep white matter hyperintensities in major depression: a neuropathological study. Arch Gen Psychiatry 59: 785-792.

Thomas AJ, Davis S, Morris C, Jackson E, Harrison R, O'Brien JT (2005). Increase in interleukin-1beta in late-life depression. $A m \mathrm{~J}$ Psychiatry 162: 175-177.

Thompson J, Thomas N, Singleton A, Piggott M, Lloyd S, Perry EK et al (1997). D2 dopamine receptor gene (DRD2) Taq1 A 
polymorphism: reduced dopamine D2 receptor binding in the human striatum associated with the A1 allele. Pharmacogenetics 7: 479-484.

Tiemeier H, Hofman A, van Tuijl HR, Kiliaan AJ, Meijer J, Breteler MM (2003). Inflammatory proteins and depression in the elderly. Epidemiology 14: 103-107.

Toescu EC, Verkhratsky A, Landfield PW (2004). Ca2+ regulation and gene expression in normal brain aging. Trends Neurosci 27: 614-620.

Valentine AD, Meyers CA, Kling MA, Richelson E, Hauser P (1998). Mood and cognitive side effects of interferon-alpha therapy. Semin Oncol 25(Suppl 1): 39-47.

Van Rossum EF, Binder EB, Majer M, Koper JW, Ising M, Modell S et al (2006). Polymorphisms of the glucocorticoid receptor gene and major depression. Biol Psychiatry 59: 681-688.

van West D, Van Den Eede F, Del-Favero J, Souery D, Norrback KF, Van Duijn CM et al (2006). Glucocorticoid receptor genebased SNP analysis in patient with recurrent major depression. Neuropsychopharmacology 31: 620-627.

Vercauterern FG, Bergeron JJ, Vandesande F, Arckens L, Quirion R (2004). Proteomic approaches in brain research and neuropharmacology. Eur J Pharmacol 500: 385-398.

Vinkers DJ, Gussekloo J, Stek ML, Westendorp RG, Van Der Mast RC (2004). The 15-item Geriatric Depression Scale (GDS-15) detects changes in depressive symptoms after a major negative life event. The Leiden 85-plus Study. Int J Geriatr Psychiatry 19: 80-84.

Volkow ND, Wang GJ, Fowler JS, Logan J, Schlyer D, Hitzemann R et al (1994). Imaging endogenous dopamine competition with $\left[{ }^{11} \mathrm{C}\right]$ raclopride in the human brain. Synapse 16: 255-262.

Vythilingam M, Chen J, Bremner JD, Mazure CM, Maciejewski PK, Nelson JC (2003). Psychotic depression and mortality. Am J Psychiatry 160: 574-576.

Vythilingam M, Vermetten E, Anderson GM, Luckenbaugh D, Anderson ER, Snow J et al (2004). Hippocampal volume, memory, and cortisol status in major depressive disorder: effects of treatment. Biol Psychiatry 56: 101-112.

Wakana S, Jiang H, Nagae-Poetscher LM, van Zijl PC, Mori S (2004). Fiber tract-based atlas of human white matter anatomy. Radiology 230: 77-87.

Whyte EM, Mulsant BH, Vanderbilt J, Dodge HH, Ganguli M (2004). Depression after stroke: a prospective epidemiological study. J Am Geriatr Soc 52: 774-778.

Willeit M, Ginovart N, Kapur S, Houle S, Hussey D, Seeman P et al (2006). High-affinity states of human brain dopamine D2/3 receptors imaged by the agonist $\left[{ }^{11} \mathrm{C}\right]-(+)-$ PHNO. Biol Psychiatry 59: 389-394.
Willeit M, Stastny J, Pirker W, Praschak-Rieder N, Neumeister A, Asenbaum $S$ et al (2001). No evidence for in vivo regulation of midbrain serotonin transporter availability by serotonin transporter promoter gene polymorphism. Biol Psychiatry 50: 8-12.

Wolkin A, Brodie JD, Barouche F, Rotrosen J, Wolf AP, Smith M et al (1989). Dopamine receptor occupancy and plasma haloperidol levels. Arch Gen Psychiatry 46: 482-484.

Wong ML, Licinio J (2004). From monoamines to genomic targets: a paradigm shift for drug discovery in depression. Nat Rev Drug Discov 3: 136-151.

Yamada M, Yamada M, Yamazaki S, Takahashi K, Nara K, Ozawa $\mathrm{H}$ et al (2001). Induction of cysteine string protein after chronic antidepressant treatment in rat frontal cortex. Neurosci Lett 301: 183-186.

Yamada M, Yamada M, Yamazaki S, Takahashi K, Nishioka G, Kudo K et al (2000). Identification of a novel gene with RING-H2 finger motif induced after chronic antidepressant treatment in rat brain. Biochem Biophys Res Commun 278: 150-157.

Yatham LN, Liddle PF, Dennie J, Shiah IS, Adam MJ, Lane CJ et al (1999). Decrease in brain serotonin 2 receptor binding in patients with major depression following desipramine treatment: a positron emission tomography study with fluorine-18-labeled setoperone. Arch Gen Psychiatry 56: 705-711.

Young RC, Gyulai L, Mulsant BH, Flint A, Beyer JL, Shulman KI et al (2004). Pharmacotherapy of bipolar disorder in old age: review and recommendations. Am J Geriatr Psychiatry 12: 342-357.

Young RC, Kalayam B, Nambudiri DE, Kakuma T, Alexopoulos GS (1999). Brain morphology and response to nortriptyline in geriatric depression. Am J Geriatr Psychiatry 7: 147-150.

Zanardi R, Artigas F, Moresco R, Colombo C, Messa C, Gobbo C et al (2001). Increased 5-hydroxytryptamine-2 receptor binding in the frontal cortex of depressed patients responding to paroxetine treatment: a positron emission tomography scan study. J Clin Psychopharmacol 21: 53-58.

Zhang X, Gainetdinov RR, Beaulieu JM, Sotnikova TD, Burch LH, Williams RB et al (2005). Loss-of-function mutation in tryptophan hydroxylase-2 identified in unipolar major depression. Neuron 45: 11-16.

Zill P, Baghai TC, Zwanzger P, Schule C, Eser D, Rupprecht R et al (2004). SNP and haplotype analysis of a novel tryptophan hydroxylase isoform (TPH2) gene provide evidence for association with major depression. Mol Psychiatry 9: 1030-1036.

Zubenko GS, Hughes III HB, Maher BS, Stiffler JS, Zubenko WN, Marazita ML (2002). Genetic linkage of region containing the CREB1 gene to depressive disorders in women from families with recurrent, early-onset, major depression. Am J Med Genet 114: $980-987$. 